\title{
Organic matter and non-refractory aerosol over the remote Southeast Pacific: oceanic and combustion sources
}

\author{
L. M. Shank ${ }^{1}$, S. Howell ${ }^{1}$, A. D. Clarke ${ }^{1}$, S. Freitag ${ }^{1}$, V. Brekhovskikh ${ }^{1}$, V. Kapustin ${ }^{1}$, C. McNaughton ${ }^{1}$, T. Campos $^{2}$, \\ and R. Wood ${ }^{3}$ \\ ${ }^{1}$ Dept. of Oceanography, University of Hawaii, Honolulu, HI, USA \\ ${ }^{2}$ National Center for Aerosol Research, Boulder, CO, USA \\ ${ }^{3}$ Dept. of Atmospheric Sciences, University of Washington, Seattle, WA, USA
}

Correspondence to: L. M. Shank (1shank@hawaii.edu)

Received: 19 May 2011 - Published in Atmos. Chem. Phys. Discuss.: 17 June 2011

Revised: 9 December 2011 - Accepted: 17 December 2011 - Published: 11 January 2012

\begin{abstract}
Submicron aerosol physical and chemical properties in remote marine air were measured from aircraft over the Southeast Pacific during VOCALS-REx in 2008 and the North Pacific during IMPEX in 2006, and aboard a ship in the Equatorial Pacific in 2009. A High Resolution - Particle Time of Flight Aerosol Mass Spectrometer (HR-ToFAMS) measured non-refractory submicron aerosol composition during all campaigns. Sulfate $\left(\mathrm{SO}_{4}\right)$ and organics $(\mathrm{Org})$, during VOCALS and the cruise show lower absolute values than those reported for previous "clean air" studies. In the marine boundary layer, average concentrations for $\mathrm{SO}_{4}$ were $0.52 \mu \mathrm{g} \mathrm{m}^{-3}$ for the VOCALS region and $0.85 \mu \mathrm{g} \mathrm{m}^{-3}$ for the equatorial region while average Org concentrations were 0.10 and $0.07 \mathrm{~g} \mathrm{~m}^{-3}$, respectively. Campaign average $\mathrm{Org} / \mathrm{SO}_{4}$ ratios were 0.19 (VOCALS) and 0.08 (equatorial Pacific). Black carbon (BC) measurements from a single particle soot photometer (SP2) and carbon monoxide (CO) concentrations over the Southeast Pacific provided sensitive indicators of pollution. $\mathrm{CO}$ and $\mathrm{BC}$ were used to identify the least polluted air, which had average concentrations of $\mathrm{SO}_{4}$ and $\mathrm{Org}$ of 0.14 and $0.01 \mu \mathrm{g} \mathrm{m}{ }^{-3}$, respectively, with an average $\mathrm{Org} / \mathrm{SO}_{4}$ of 0.08 . Data from IMPEX was constrained to similar clean air criterion, and resulted in an average $\mathrm{Org} / \mathrm{SO}_{4}$ ratio of 0.19 . Under the cleanest MBL conditions during VOCALS, identified by $\mathrm{CO}$ below $61 \mathrm{ppbv}$, a robust linear relationship between Org and BC concentrations revealed that even at very low pollution levels, combustion sources dominated organic aerosol, suggesting little to no marine source of submicrometer Org to the atmosphere over the eastern South Pacific. This means marine organics cannot be identified by merely setting a standard for background conditions below which anthropogenic influence can
\end{abstract}

be disregarded. Other methods must be used to exclude nonmarine sources.

\section{Introduction}

Aerosols play an important role in the radiative balance of Earth's atmosphere, as they affect planetary albedo, thus climate, through the scattering of solar radiation (direct effect) and their ability to alter the lifetime and optical properties of clouds (indirect effect) (Charlson et al., 1987, 1992; Twomey, 1974). In the marine boundary layer (MBL) over the remote ocean and far removed from anthropogenic influences, the ocean surface is a major source of aerosol mass and number. This includes the primary emission of sea-salt particles from wave breaking and bubble bursting, as well as gas to particle conversion of vapors emitted to the atmosphere from oceanic phytoplankton (i.e. dimethylsulfide (DMS)) (Andreae and Raemdonck, 1983; Grenfell et al., 1999). Another source of aerosols to the remote MBL is entrainment from the free troposphere (FT) (Clarke et al., 1998). Long range transport of pollution, as well as local sources of aerosols, can increase aerosol and cloud condensation nuclei $(\mathrm{CCN})$ concentrations in these remote areas, thus potentially affecting the local albedo and cloud properties (Clarke et al., 2001; Clarke and Kapustin, 2010; Jaffe et al., 1999).

The roles of sea-salt aerosol and non-sea-salt sulfates in climate processes (Andreae and Barnard, 1984; Cline and Bates, 1983) have long motivated investigations of marine aerosol. However, as significant concentrations of organic aerosol (OA) have been observed at sites believed to represent clean marine conditions (Hoffman and Duce, 1976; 
Kleefeld et al., 2002; Middlebrook et al., 1998; Novakov et al., 1997; Putaud et al., 2000), the possibility of an oceanic OA source to the fine aerosol mode has been under investigation. More recently, at Mace Head, Ireland, an oceanic sampling site in the North Atlantic, relatively large amounts of OA (up to $72 \%$ of total aerosol mass) have been linked to increased biological production (O'Dowd et al., 2004; Spracklen et al., 2008), suggesting that biogenic emissions are an important source of both water-soluble and insoluble organic matter to the MBL. Satellite-derived mean chlorophyll- $a$ concentrations have been weakly correlated $\left(R^{2} \sim 0.25\right)$ with OA concentrations in clean marine aerosols collected there. In other studies, correlations between trajectory weighted chlorophyll- $a$ and OA were also found for aerosols collected at Amsterdam Island $\left(R^{2}=0.60\right)$ and Mace Head $\left(R^{2}=0.75\right)$, however no relationship between chlorophyll- $a$ and OA was found for clean marine aerosols collected at the Azores (Spracklen et al., 2008). Zorn et al. (2008) found up to $51 \%$ of submicron non-refractory mass attributed to OA during a phytoplankton bloom in the South Atlantic but noted trajectories were recently over land.

Sulfates (ultimately from dimethylsulfoniopropionate (DMSP)) and organic matter (primary and secondary) are of particular interest as they provide mechanisms for marine biota to affect aerosol population. Initially most scientific attention was paid to the DMS branch, as $\mathrm{SO}_{4}$ typically dominates submicron aerosol under clean marine conditions (e.g. Charlson et al., 1987). However, DMSP is only produced by a subset of phytoplankton, notably including dinoflagellates, prymnesiophytes, and perhaps some picoeukaryotes (Gabric et al., 2008). Similarly, production of primary marine organics varies dramatically between species, with some species such as the diatom Melosira arctica producing prodigious quantities of organic material that have been detected in aerosol (Orellana et al., 2011). Thus it is unsurprising that the ratio of marine-origin sulfates to organic matter varies regionally and with season as a function of plankton composition and physiological condition. Such differences are evident in the studies mentioned above. As sulfates and organics have disparate hygroscopic properties, regional differences in this ratio may influence cloud condensation nuclei.

Given the ubiquity of anthropogenic pollution, it is a challenge to isolate the physical and chemical properties of those aerosols that are actually of marine origin. Many studies have attempted to describe background conditions by taking marine aerosol measurements from land sites and ships (Allan et al., 2004; Andreae et al., 1999; Lohmann et al., 2005; Phinney et al., 2006; Quinn and Bates, 2003; Yoon et al., 2007). During these campaigns, various criteria for "clean" marine conditions were implemented, and included parameters such as clean sector wind direction (Andreae et al., 1999; Yoon et al., 2007), particle number concentration below a certain threshold, Air Mass Back Trajectories (AMBTs) used to indicate air masses with no continental influence a certain number of days before collection took place (Quinn and
Bates, 2003), or volatile organic carbon (VOC) tracers (Allan et al., 2004). However, unless aerosols from continental sources far upwind have been effectively removed by precipitation, AMBTs and clean sectors cannot effectively exclude non-marine influence. Coastal sites can also be influenced by high productivity near shorelines (Spracklen et al., 2008). As a result, most of these studies make no claims about what fraction of "clean" aerosol is actually from the ocean.

As a product of incomplete combustion, black carbon (BC) is an unambiguous indicator of non-marine aerosol; whenever $\mathrm{BC}$ aerosol is found in a marine air mass it must be accompanied by other aerosol products of combustion, including OA. There are three obvious ways to handle the presence of continental influence in order to define background marine conditions: (1) try to subtract out the non-marine aerosol; (2) develop a tracer that directly indicates the marine contribution; or (3) develop thresholds which, when met, assure that contamination is negligible compared with marine sources (the methodology used in some of the studies described above). The first is difficult, as it requires a tracer quantitively linked to continental organic matter (OM). BC itself is an obvious choice, but reported $\mathrm{OM}: \mathrm{BC}$ ratios near source regions range widely: $20: 1$ and $34: 1$ for southwesterly and northwesterly flow from the northeast coast of the US (Bates et al., 2005), 85:1 for fresh and 25:1 for aged Canadian forest fires (Singh et al., 2010), 1:1 from southwest India and 8:1 from northeast Asia (Quinn and Bates, 2005; INDOEX and ACE-Asia:polluted), and 8:1 from southern Africa (Haywood et al., 2003). Reid et al. (2005) show $\mathrm{OC}$ :BC ranging from 2 to 17 for a wide range of biomass burning, though they cluster around 11. Carbon isotopes have been used as tracers of marine organics, allowing a few groups to calculate marine and continental contributions to OM. Turekian et al. (2003), Narukawa et al. (2008), and Miyazaki et al. (2010) used ${ }^{13} \mathrm{C}$ and Ceburnis et al. (2011) used ${ }^{14} \mathrm{C}$ as well. In general, evidence for large contributions of OA to marine aerosol come from studies at high latitudes or during phytoplankton blooms. Even at high latitude sites, air from the subtropics tends to have much lower organic content. At Mace Head, Dall'Osto et al. (2010) found that winds from the south had $\mathrm{Org} / \mathrm{SO}_{4} \approx 0.17$. At Amsterdam Island, Sciare et al. (2009) found low OM during Austral winter, and when back trajectories were from the north. Both the Dall'Osto et al. and Sciare et al. studies found $\mathrm{BC}$ (45 and $7 \mathrm{ng} \mathrm{m}^{-3}$, respectively) and neither attempted to isolate the purely marine contributions, which must have been lower. Claeys et al. (2010) found Org mass contributes less than $10 \%$ to total submicron mass in aerosols collected at Amsterdam Island, even during periods of high biological production. Zorn et al. (2008), reported $\mathrm{Org} / \mathrm{SO}_{4}$ ratios of 0.07 and 0.17 for the Antarctic and South Atlantic oceans, but had no BC or CO data. Of the carbon isotope tracer studies mentioned above, only Miyazaki et al. (2010) documented air masses from subtropical regions during nonbloom periods. They found that only $8-36 \%$ of the OM was 
due to marine sources during samples with back trajectories that originated over the oligotrophic central North Pacific before crossing narrow high-productivity areas to reach the ship they were sampling from. It's not clear how much of the aerosol was contributed by the low-productivity region. Elemental carbon (EC) during the subtropical events in the Miyazaki et al. (2010) study averaged $43 \mathrm{ng} \mathrm{m}^{-3}$. Less directly, hygroscopic growth experiments in the Southern Atlantic and Indian Oceans (Maßling, 2003), the Pacific and Southern Oceans (Berg et al., 1998), near Puerto Rico (Allan et al., 2008) and the Eastern Atlantic (Allan et al., 2009) all found hygroscopic growth of aerosol particles consistent with particles composed chiefly of sulfate salts rather than OM during clean marine periods.

Here we present two studies conducted in the central and southeast Pacific Ocean that show significantly lower absolute and relative contributions of Org to the total submicron aerosol mass than previously reported. A rapid, accurate BC measurement showed a linear relationship between $\mathrm{BC}$ and Org over the southeast Pacific, even at low concentrations of $\mathrm{CO}$ and $\mathrm{BC}$. Another campaign that took place over the North Pacific Ocean showed similar low $\mathrm{Org} / \mathrm{SO}_{4}$ ratios to those in the Southeast Pacific (SEP), when constrained to increasingly more stringent $\mathrm{CO}$ and $\mathrm{BC}$ concentrations. These results will be discussed and compared with previous investigations of clean marine aerosol. The use of the mass fraction of Org relative to $\mathrm{SO}_{4}\left(\mathrm{Org} / \mathrm{SO}_{4}\right)$ will be used to demonstrate that under the clean conditions established in this study, little of the submicron non-refractory aerosol mass can be attributed to Org. Org and $\mathrm{SO}_{4}$ are typically the two largest components of submicron aerosol mass and are therefore two components that are commonly and consistently measured. Though Org and $\mathrm{SO}_{4}$ have different production rates and chemical reactivity in the atmosphere, the ratio of $\mathrm{Org} / \mathrm{SO}_{4}$ is a useful and convenient tool for comparing non-refractory submicron aerosol chemical composition across different geographical regions.

\section{Methods}

\subsection{Field campaigns}

Submicron aerosols were collected during two campaigns over the Southeast and Central Pacific shown in Fig. 1. The VAMOS Ocean-Cloud-Land-Study Regional Experiment (VOCALS-REx), took place in October/November 2008 out of Arica, Chile. The campaign involved 14 research flights aboard the National Center for Aerosol Research (NCAR) C-130, with three distinct flight patterns (Wood et al., 2011b). These included (1) flights along $20^{\circ} \mathrm{S}$ with 10 min legs above-cloud, in-cloud and below cloud, (2) flights investigating pockets of open cells (POCs) in the stratocumulus deck (Wood et al., 2011a), and (3) two pollution surveys to $30^{\circ} \mathrm{S}$ parallel to the coast of Chile. Submicron particles were also sampled in the MBL on board the NOAA ship R/V Ka'imimoana over the central Pacific during August/September 2009. The cruise originated in Hawaii and serviced Tropical Atmosphere Ocean (TAO) buoys along the $140^{\circ} \mathrm{W}$ and $125^{\circ} \mathrm{W}$ longitudes, from $8^{\circ} \mathrm{N}$ to $8^{\circ} \mathrm{S}$.

A third campaign, the Intercontinental and Megacity Pollution Experiment (IMPEX), also took place aboard the C130 in April 2006, with 12 research flights from Seattle, WA over the Northeast Pacific Ocean. Most of these flights were designed to intercept transported Asian pollution layers as identified by chemical transport models (Dunlea et al., 2009) in between continents, namely between Asia and North America. Both the aging of aerosols and the structure of the pollution layers were investigated. For comparison against pollution aerosol, several instances of clean marine air were measured, even though clean aerosol was not the focus of the campaign.

\subsection{Instrumentation}

\subsubsection{Inlets}

A Solid Diffuser Inlet (SDI) was used on board the C-130 for the majority of sample collection during VOCALS and IMPEX. The inlet was kept isokinetic during sampling by adjusting flows as flight parameters (i.e. speed, altitude, etc.) changed. Inlet losses from the SDI are most severe for large, supermicron particles (Moore et al., 2004). Moore et al. (2004) performed an inlet comparison study and found the SDI to effectively pass submicrometer, as well as optically relevant coarse mode aerosol. McNaughton et al. (2007) tested University of Hawai'i's SDI against ground based measurements during the DC-8 Inlet Characterization Experiment (DICE) and found that submicrometer scattering agreed within $16 \%$. The inlet efficiently transmits both dust and sea salt particles smaller than about $4 \mu \mathrm{m}$ (50\% cut-off) in dry diameter. While most of the instrument inlets are not relative humidity $(\mathrm{RH})$ controlled, several mechanisms are in place to ensure aerosol is dry $(<40 \%)$ before it is measured by any instrument used in the discussion of this paper. For example, ram heating decreases aerosol RH as it enters the aircraft. We also use dilution with equal amounts of desiccated and filtered air to drop the RH to between 20 and $30 \%$ in some instruments (i.e. Optical Particle Counter, Howell et al., 2006). Aerosol sampled by the aerosol mass spectrometer is not desiccated, but the drop in pressure from the inlet to the intermediate pressure chamber ensures aerosol is below a RH of $40 \%$ before it is ionized. Five-minute filter periods were conducted a minimum of twice per 9-h flight, usually in the beginning and at the end of flights. Filter periods during the cruise occurred once a day, and were at least $30 \mathrm{~min}$.

On the R/V Ka'imimoana, $3 / 4$ inch copper tubing $(\sim 30 \mathrm{~m})$ was used to bring air from the bow of the ship (forward of the stack) to the instruments housed inside the ship. The flow rate was approximately 401 per minute $(\mathrm{lpm})$, and 
gravitational losses and diffusional losses for particles between 0.1 and $1 \mu \mathrm{m}$ were estimated at $<5 \%$ (using Baron and Willeke, 2001). The sampling RH throughout the campaign was $56.2 \pm 4.8 \%$.

\subsubsection{Aerosol mass spectrometer}

During the VOCALS and IMPEX campaigns, as well as the TAO cruise, non-refractory chemical composition of submicron aerosols was determined using an Aerodyne High Resolution Time of Flight Mass Spectrometer (HR-ToF-AMS). The HR-ToF-AMS uses an aerodynamic lens assembly to focus $35 \mathrm{~nm}-1 \mu \mathrm{m}$ vacuum aerodynamic diameter particles onto a $600^{\circ} \mathrm{C}$ heated surface (Zhang et al., 2002, 2004). Particles are evaporated off the heater, ionized by electron impaction $(70 \mathrm{eV})$, and mass analyzed by ToF-MS. The AMS was typically operated in high-sensitivity mode (V-mode), though on the ship and occasionally during VOCALS, the instrument was operated in a high resolution mode (W-mode), which offers more detailed chemical composition of ion fragments. A detailed description of the instrument and its operation is given in DeCarlo et al. (2006) and Canagaratna et al. (2007). During VOCALS the AMS was operated with an intermediate-pressure chamber that kept the pressure at the aerodynamic lens constant $(600 \mathrm{mbar})$ regardless of pressure changes due to changing altitude. The pressure drop also reduced $\mathrm{RH}$, as mentioned in the previous section.

Typical detection limits for one-minute averaged V-mode data have been reported as $<0.04 \mu \mathrm{g} \mathrm{m}^{-3}$ for all chemical species $\left(\mathrm{SO}_{4}, \mathrm{Org}\right.$, nitrate $\left(\mathrm{NO}_{3}\right)$, and ammonium $\left.\left(\mathrm{NH}_{4}\right)\right)$ (DeCarlo et al., 2006). However, these detection limits were derived from ground-based experiments. Aircraftbased AMS detection limits are typically $2-5$ times higher due to higher background because the instrument has to be turned off between flights. When the turbo pumps on the AMS are off it allows the build up of material inside the vacuum chamber. For several hours after the AMS is turned back on, this material is driven out of the system by the heater. For some material, e.g. Org, this can take longer than our typical $2 \mathrm{~h}$ preflight warm up. Consequently, early in the flights there can be a high Org background which contributes to more noise and a higher detection limit. Detection limits for our campaigns were calculated as twice the standard deviation of the species signal during a filter period. For example, during VOCALS the detection limit varied depending on the duration of AMS operation over a flight, and with lower detection limits reached after several hours. The detection limit changed from $0.02 \mu \mathrm{g} \mathrm{m}^{-3}$ at the beginning of a flight $(2 \mathrm{~h}$ after the turbo pumps were turned on), to $0.014 \mu \mathrm{g} \mathrm{m}^{-3}$ in the middle of a flight $(6.5 \mathrm{~h}$ into the flight, or $8.5 \mathrm{~h}$ after the pumps were turned on). Detection limits are for one-minute integrated data, which is the highest time resolution of data reported in this study. Data which were under the detection limit of the instrument were removed from the analysis.
Due to the high Org background at the beginning of the flight that was made apparent by a combination of operating parameters and low Org signal in the VOCALS region, the Org closed signal was adjusted to help account for the high background, and change negative Org values to physically plausible values. A new closed signal was calculated by averaging the closed signals on either side of an open signal. The difference between the new closed signal and the corresponding open signal equaled the new Org concentration. The result of the Org background correction was a maximum of $0.05 \mu \mathrm{g} \mathrm{m}^{-3}$ increase in Org values in the beginning of the flight (for the first hour of the flight), after which the correction had negligible impact on Org values $\left(\ll 0.01 \mu \mathrm{g} \mathrm{m}^{-3}\right)$.

Processing of the AMS data was done using the standard AMS data analysis software (SQUIRREL v.1.48C and PIKA v.1.07B, Sueper, 2010) within Igor Pro 6 (Wavemetrics, Lake Oswego, OR). The fragmentation table in SQUIRREL was adjusted to give zero Org mass concentrations during filter periods. The adjustment was achieved by altering the air mass fragment coefficient at $\mathrm{m} / z 29$ (frag_air[29]). The default coefficient is used to represent an isotopic factor and describes the relative amount of $\mathrm{N}^{15} \mathrm{~N}$ at $\mathrm{m} / z 29$, which is related to the signal of $\mathrm{N}_{2}$ at $\mathrm{m} / \mathrm{z} 228$. However, depending on the threshold setting and possible saturation effects, this isotopic factor may be slightly different than predicted, and may be multiplied by a factor, close to 1 . In our case, the isotopic factor was adjusted up to give zero Org signal at $\mathrm{m} / \mathrm{z}$ 29 during a filter period. The constant applied to the default coefficient of the air peak at $\mathrm{m} / \mathrm{z} 29$ did not change during a flight, and changed very little over the campaign. The average value was $0.77 \pm 0.08$, representing a $10 \%$ variation which corresponds to an uncertainty of $0.02 \mu \mathrm{g} \mathrm{m}^{-3}$ for Org values.

The overall ability of the AMS to transmit and detect particles is called the collection efficiency (CE) and takes into account the transmission efficiency of the aerodynamic lens, the loss of transmission because of non-sphericity, and the efficiency with which a vaporized particle is detected (Huffman et al., 2005). The CE of the AMS for the inorganic ions was estimated by comparing the molar ratio of $\mathrm{NH}_{4}$ to $\mathrm{SO}_{4}$ to determine the acidity of the aerosol. More acidic aerosols (i.e. lower $\mathrm{NH}_{4} / \mathrm{SO}_{4}$ molar ratio) are collected more efficiently than neutralized aerosol (Drewnick et al., 2003). The CE correction factor was determined by finding the $\mathrm{NH}_{4} / \mathrm{SO}_{4}$ over the desired collection time, and assuming $\mathrm{CE}$ varies linearly (from 50 to $100 \%$ ) as the ratio of $\mathrm{NH}_{4} / \mathrm{SO}_{4}$ decreases from 1 to 0 (Matthew et al., 2008). Any time the $\mathrm{NH}_{4} / \mathrm{SO}_{4}$ ratio is above 1 , the CE is assumed to be $50 \%$.

The ionization efficiency (IE) calibration determines the ionization efficiency of ammonium nitrate $\left(\mathrm{NH}_{4} \mathrm{NO}_{3}\right)$. The quantification of all non-refractory AMS components $\left(\mathrm{SO}_{4}\right.$, $\mathrm{NH}_{4}$, and $\mathrm{Org}$ ) are based on the linearity of the IE of $\mathrm{NO}_{3}$ (Jimenez, 2010). These are typically done in the field using Brute-Force Single Particle Mode (BFSP). IE calibrations were run once a week (every three flights) throughout 


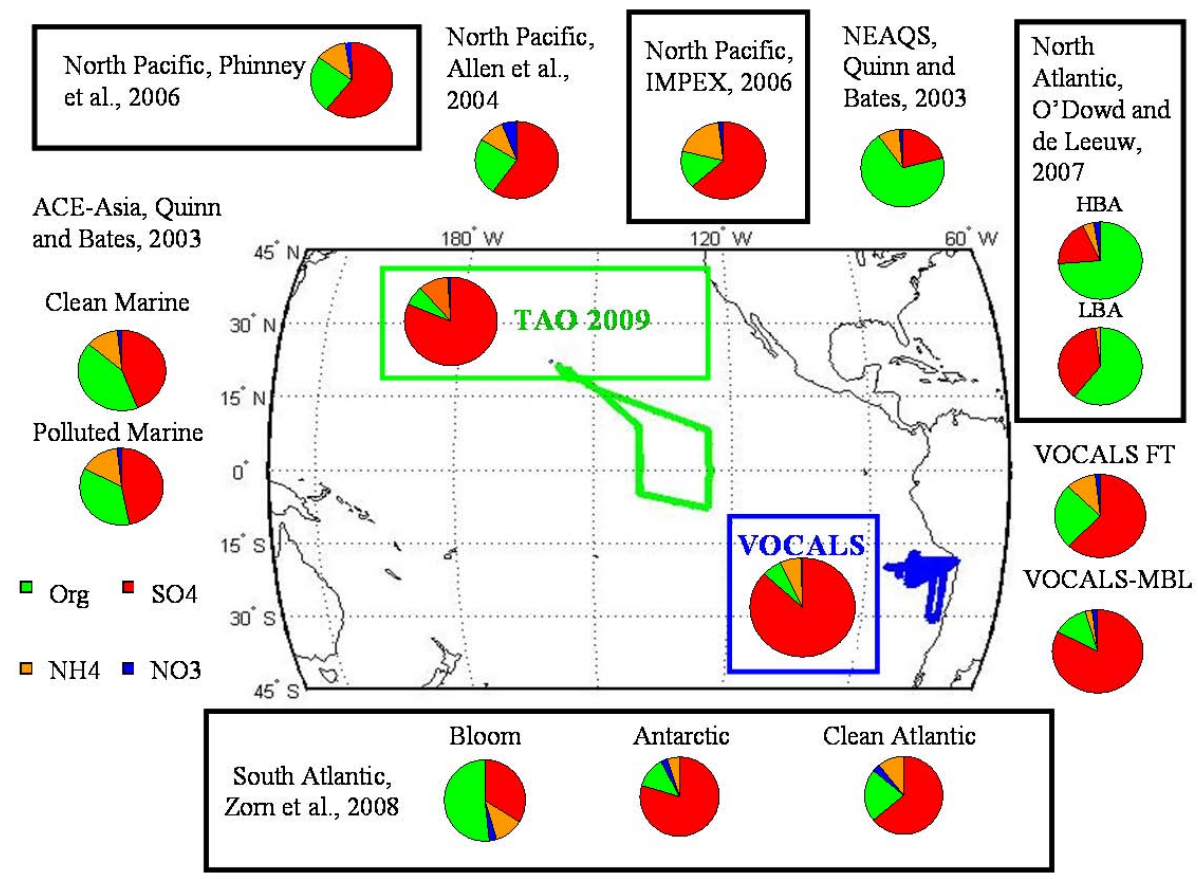

Fig. 1. Study region for VOCALS (blue) and TAO 2009 cruise (green). Pie charts indicate relative contributions of submicron non-refractory species. All studies are of marine boundary layer aerosols, with the exception of the VOCALS Free Troposphere data (FT). Studies in bold boxes indicate those which focus on "clean" marine aerosol, (i.e. based upon various approaches to minimize continental influence). NEAQS = New England Air Quality Study, HBA = High Biological Activity, LBA = Low Biological Activity.

VOCALS using generated $\mathrm{NH}_{4} \mathrm{NO}_{3}$ aerosol. An IE calibration was run at the beginning of the TAO 2009 cruise. However, the chopper wheel stopped working half way through the campaign, and therefore no additional IE calibrations were run.

Total uncertainty for the AMS, including errors due to fluctuations of voltages, filament current, particle losses, counting statistics, and IE calibrations (Drewnick, 2006) as well as collection efficiency and fragmentation table corrections, is $\pm 28 \%+0.06 \mu \mathrm{g} \mathrm{m}^{-3}$ for Org values and $\pm 27 \%+0.01$ for $\mathrm{SO}_{4}$ values.

For the purposes of this study the term Org, which is used in the AMS community to represent the amount of particulate organic matter (POM) resolved by the AMS, is used interchangeably with POM from e.g. Quinn and Bates (2003).

\subsubsection{Single particle soot photometer}

A single particle soot photometer (SP2) was also used to measure $\mathrm{BC}$ particle number and mass during IMPEX and VOCALS. The detector configuration and triggering method were set up according to the manufacturer (Droplet Measurement Technologies (DMT)) as described in Stephens et al. (2003) and Schwarz et al. (2006). The detector configuration was set to use photomultiplier tubes (PMTs) for two incandescence channels (broad/narrow) and avalanche photodiodes (APDs) employed for two scattering channels. Dur- ing VOCALS, events were triggered from broad incandescence channels. The incandescence channel response was converted to refractory $\mathrm{BC}$ mass using a calibration curve generated with laboratory black carbon (Aquadag), sized using a long differential mobility analyzer (LDMA, described in Sect. 2.2.4). The effective density of Aquadag was generated according to (Moteki and Kondo, 2010). Detection limits of $0.087-400 \mathrm{~nm}$ were calculated assuming a BC density of $2 \mathrm{~g} \mathrm{~cm}^{-3}$. For a sampling interval of $1 \mathrm{~min}$, the total uncertainty of the SP2 is $\pm 23 \%$ including calibration errors, fluctuations in laser power, pressure dependencies (Schwarz et al., 2006) and counting statistics. While it is common that a significant number of $\mathrm{BC}$ particles may exist below the limit of SP2 detection, in the case of remote aged atmospheric soot we generally find the SP2 misses less than $10 \%$ of the ambient BC mass (Schwarz et al., 2010). If particle losses were significant we would expect a positive intercept for regression of absorption against SP2 BC mass but this is not what we find (e.g. McNaughton et al., 2011). We note that recently it has been argued by Gysel et al. (2011) that the effective density of Aquadag is about $35 \%$ lower than found by Moteki and Kondo (2010). If so, the BC measurements reported here are correspondingly too high. However, this does not change the nature of the dependencies identified in this study and our BC measurements have not been altered to reflect the Gysel et al. findings. 


\subsubsection{Other aerosol instrumentation}

This study utilizes data from several other aerosol instruments used on board the C-130. Particle concentrations were continuously monitored with condensation nuclei $(\mathrm{CN})$ counters (TSI 3010). Two CN counters were operated in parallel; one with an inlet heated to $360^{\circ} \mathrm{C}$. Non-volatile $\mathrm{CN}$ (CNhot) refers to those particles which do not volatilize at $360^{\circ} \mathrm{C}$, i.e. $\mathrm{BC}$, sea-salt, non-volatile organic species and some larger sizes that are incompletely volatilized. In the absence of sea-salt (e.g. in the FT) these characteristics allow CNhot to serve as a proxy for pollution (Clarke and Kapustin, 2002, 2010). An Optical Particle Counter (OPC), LAS-X with modified electronics, was also operated using a heated inlet which cycled between non-heated, 150, 300, and $400^{\circ} \mathrm{C}$. The OPC sampling time varied between 1-2 min depending on temperatures selected for each cycle (typically 30 s per temperature). Total and non-volatile size distributions of the aerosol (Clarke, 1991) over about 120-1000 nm can be measured with the OPC. Uncertainties estimated by Shinozuka et al. (2004) for the OPC are $\pm 15 \%$. A long differential mobility analyzer (LDMA, model TSI 3934) with modified flow control, electronics, and data acquisition was used to acquire size distributions in the $10-500 \mathrm{~nm}$ range. The LDMA drew air from an all-aluminum lagged aerosol grab (LAG) chamber, which is open for $\sim 20 \mathrm{~s}$ every $2 \mathrm{~min}$ (Clarke et al., 1998). The LDMA was operated in a scanning mode, with an upscan time of $60 \mathrm{~s}$. The inversions were done using a LabView program written by J. Zhou and described in his dissertation (Zhou, 2001). The LDMA uncertainties include flow rate (both sheath and sample flow), and errors in sizing, including those resulting from non-sphericity of the particles. Total uncertainties for the instrument are estimated at $\pm 30 \%$. A three-wavelength TSI nephelometer (model 3563$)$ and impactor system provided data on total and submicrometer dry aerosol light scattering. $\mathrm{CO}$ was measured on the C-130 (IMPEX and VOCALS) using a vacuum UV resonance fluorescence instrument similar to that of Gerbig et al. (1999). Precision is reported as $\pm 3 \mathrm{ppb}$ and accuracy as better than $10 \%$ for a mixing ratio of $100 \mathrm{ppb}$ (Pfister, 2010). Instrumentation aboard the Ka'imimoana included the AMS, CN counters (heated and unheated), nephelometer, and LDMA.

\section{Results}

\section{Data stratification}

As a test of AMS performance, submicron non-refractory AMS mass was compared to submicron aerosol volume determined from size distributions measured by the LDMA, assuming a particle density of $1.7 \mathrm{~g} \mathrm{~cm}^{-3}$ for dry sulfate. Although OM has been shown to have a lower density than that of $\mathrm{SO}_{4}$ when sampled by the AMS (Cross et al., 2007), given the high mass fraction of $\mathrm{SO}_{4}(>75 \%)$ and the low contribution of Org $(<10 \%)$ in the VOCALS and TAO regions, the assumption of $1.7 \mathrm{~g} \mathrm{~cm}^{-3}$ is justified for the purposes of this analysis. This comparison between LDMA and AMS mass provided an independent assessment of potential particle losses by the AMS. Figure 2 shows a plot of AMS mass and LDMA mass for the VOCALS marine boundary layer (MBL) that yields a linear regression equation with a slope of $0.65, R^{2}=0.68$, suggesting that the AMS was under sampling submicron aerosol compared to the LDMA $\left(\mathrm{LDMA}_{\text {before }}\right)$. Consequently, LDMA volumes were corrected for non-volatile mass determined independently by the OPC. The volatile mass from the OPC was calculated as the difference between the non-heated mass (M1) and the mass that volatilized at $400{ }^{\circ} \mathrm{C}(\mathrm{M} 4)$ over the same size bins as the LDMA $(\sim 10-500 \mathrm{~nm})$. The fraction of volatile OPC mass $(\mathrm{Vol})$ was then calculated using $\mathrm{Vol}=(\mathrm{M} 1-\mathrm{M} 4) / \mathrm{M} 1$. A histogram of the Vol fraction is shown in Fig. 2. The measured Vol fraction from the OPC was multiplied by the measured LDMA mass over the closest available time period (within approximately $90 \mathrm{~s}$ ) in order to estimate only the volatile LDMA mass expected to be detected by the AMS. This LDMA volatile mass was then compared with the AMS, and is plotted in Fig. 2 as black circles over the uncorrected data in grey. After this correction, the slope of the linear regression between the LDMA and AMS improved to 0.81, $R^{2}=0.65$, indicating better quantitative agreement with the non-refractory aerosol component, and within the expected uncertainties of the instruments (between 25-30\%). The comparison between LDMA, OPC, and AMS is complicated by incommensurate timescales which make more direct comparisons difficult. The AMS and OPC data are averaged over $90 \mathrm{~s}$ timescales in order to compare with the LDMA, and even then the AMS spends half the sampling time in a "blanking" mode. The LDMA size distributions represent a $20 \mathrm{~s}$ grab sample that is then scanned over a $60 \mathrm{~s}$ period. Selecting only periods of most stable conditions might reduce variability at the expense of fewer data, but would not affect the overall slope.

Throughout VOCALS, dedicated intercomparison periods took place between sampling platforms. These consisted of level legs where aircraft and/or the R/V Ron Brown sampled the same air mass for a given amount of time, allowing direct comparison of instrument performance across platforms. Detailed descriptions of intercomparison periods can be found in Allen et al. (2010). Other aircraft involved in the campaign, and with an AMS on board, included the United Kingdom (UK) British Aerospace-146 (BAe-146), and the United States Department of Energy Gulfstream-1 (DoE-G1). AMS data across all platforms was found to contain no systematic sampling biases, and mean quantities from intercomparison runs agreed within one standard deviation (Allen et al., 2010). The comparison between the BAe-146 and C-130 AMS data showed agreement within $20 \%$ for the absolute values of $\mathrm{Org}$ and $\mathrm{SO}_{4}$, and showed less than $6 \%$ disagreement in the $\mathrm{Org} / \mathrm{SO}_{4}$ ratio. 


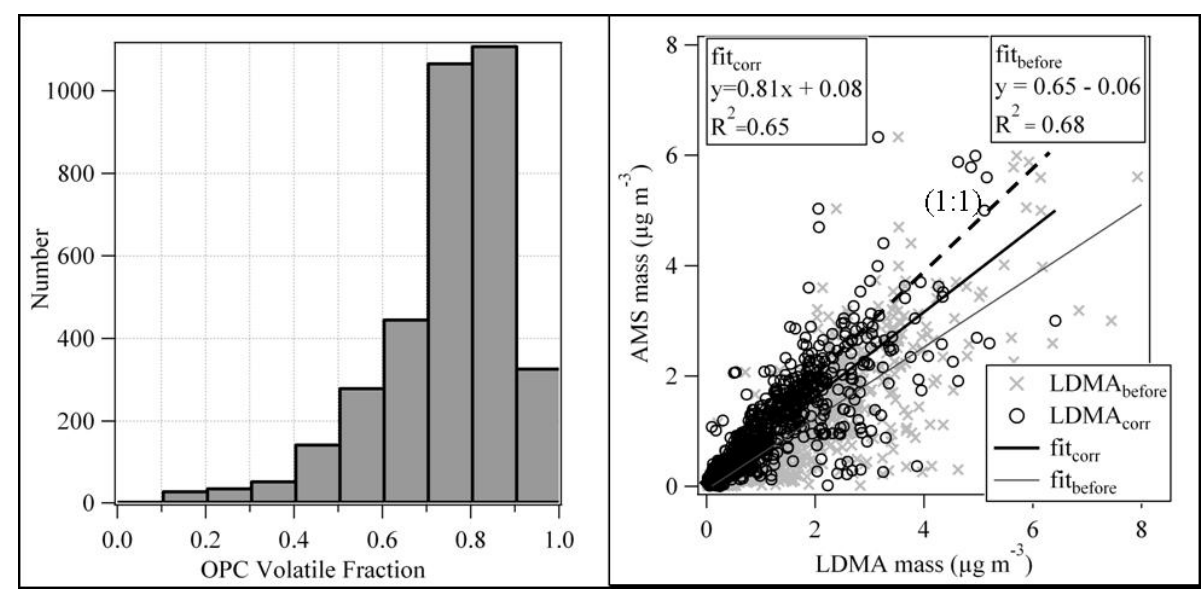

Fig. 2. (Left) Histogram of the volatile fraction established from the OPC. (Right) Relationship between LDMA volatile mass and AMS mass for the VOCALS MBL before and after the non-volatile correction factor.

However, the agreement between the Ron Brown and C130 AMS data during intercomparison periods was not as consistent. The AMS on board the Ron Brown was an Aerodyne Quadrupole AMS (Q-AMS), with significantly higher detection limits for Org $\left(0.16 \mu \mathrm{g} \mathrm{m}^{-3}\right)$ than the ToF-AMS operated aboard the aircraft. Therefore, when intercomparisons were conducted during periods with Org concentrations near the detection limit of the Q-AMS, the discrepancies between platforms were worse than during periods of elevated Org concentrations. During one of the latter periods, the C-130 AMS measured $0.26 \pm 0.06 \mu \mathrm{g} \mathrm{m}^{-3}$ Org and $0.96 \mu \mathrm{g} \mathrm{m}^{-3} \pm 0.02 \mathrm{SO}_{4}$ while the Ron Brown AMS measured $0.42 \pm 0.09 \mu \mathrm{g} \mathrm{m}^{-3}$ Org and $0.90 \pm 0.11 \mu \mathrm{g} \mathrm{m}^{-3} \mathrm{SO}_{4}$. Given the uncertainties of the two different AMS instruments for Org; C-130 AMS uncertainty $\pm 28 \%+0.06 \mu \mathrm{g} \mathrm{m}^{-3}$ from Sect. 2.2.2 and Ron Brown AMS uncertainty of $\pm 25 \%+0.16 \mu \mathrm{g} \mathrm{m}^{-3}$ (Canagaratna et al., 2007), the Org measurements agree within the expected uncertainties.

Table 1 shows the average concentrations for $\mathrm{SO}_{4}$, Org, $\mathrm{NO}_{3}$, and $\mathrm{NH}_{4}$ for VOCALS and TAO 2009, as well as average $\mathrm{BC}$ mass and $\mathrm{CO}$ for VOCALS. In addition, average values of these aerosol constituents and the average $\mathrm{Org} / \mathrm{SO}_{4}$ ratio from several previous clean marine investigations (Fig. 1) are shown for comparison. While some previous investigations focus on clean marine aerosol by excluding only local sources, others (shown in bold boxes in Fig. 1) attempt to quantify a background marine aerosol for a particular region. In Table 1, our VOCALS data is averaged based on three different criteria. The first is simply campaign-averaged MBL, the second is the nominally clean MBL, with data restricted to $\mathrm{BC}$ mass less than $4.5 \mathrm{ng} \mathrm{m}^{-3}$ and CO less than $61 \mathrm{ppb}$. Finally, our criteria for the natural unperturbed MBL as determined during this study, also described in Sect. 4.1.

Data from the TAO 2009 cruise had to be screened for ship contamination. Periods influenced by the ship's plume were removed from the AMS data based upon exceeding a cri- teria of $700 \mathrm{~cm}^{-3}$ for CNhot and $15 \mathrm{Mm}^{-1}$ for submicron scattering values from the TSI nephelometer. Next, CNhot ( $1 \mathrm{~Hz}$ data) was smoothed with a 12-point median filter. The smoothed data was subtracted from the raw data in order to capture any rapid changes in the concentration possibly related to stack contamination. Any data point where the difference in raw and smoothed data, on a one second time scale, was greater than a concentration of 200 particles $\mathrm{cm}^{-3}$ was removed. After this screening the same CE scheme employed for the VOCALS data was applied. The resulting average concentration of $\mathrm{SO}_{4}$ was $0.85 \mu \mathrm{g} \mathrm{m}^{-3}$, while $\mathrm{Org}$ was $0.07 \mu \mathrm{g} \mathrm{m}^{-3}$. $\mathrm{NH}_{4}$ concentrations averaged $0.11 \mu \mathrm{g} \mathrm{m}^{-3}$. Time series of TAO cruise data for $\mathrm{SO}_{4}, \mathrm{Org}, \mathrm{NH}_{4}$ and $\mathrm{NO}_{3}$ are shown in Fig. 3, along with the time series of Org/SO $\mathrm{S}_{4}$. Figure 3 also includes the cruise track with date labels, rain events, and wind direction indicated. Excursions from the average $\mathrm{Org} / \mathrm{SO}_{4}$ ratio are pronounced along the easternmost leg of the cruise, along $125^{\circ} \mathrm{W}$ from $8^{\circ} \mathrm{S}$ to $5^{\circ} \mathrm{N}$, where Org concentrations increase gradually from $0.07 \mu \mathrm{g} \mathrm{m}^{-3}$ at the southern end of the cruise track, to $0.17 \mu \mathrm{g} \mathrm{m}^{-3}$ near the equator. As the ship moved north after 15 September, and north of the Intertropical Convergence Zone (ITCZ), the $\mathrm{Org} / \mathrm{SO}_{4}$ ratio decreased to values below 0.1 , typical of those observed elsewhere during the cruise, while the absolute value of Org also decreased back to concentrations typical of the cruise average $0.07 \mu \mathrm{g} \mathrm{m}^{-3}$.

The AMS was operated in both $\mathrm{V}$ and $\mathrm{W}$ modes during the cruise, cycling between the two modes every one and four minutes, respectively. When cycling between the two modes, ten-minute averages include only two minutes of Vmode data, compared to ten minutes of data when operating solely in V-mode. Due to the condition of the AMS, we were able to operate the instrument only in V-mode after 10 September. Since the current study focuses on V-mode data exclusively, the data are therefore noisier before 10 September than after. 
Table 1. Average submicron mass concentrations for major aerosol constituents from current and previous investigations of "clean" marine submicron aerosol ${ }^{\mathrm{a}}$.

\begin{tabular}{|c|c|c|c|c|c|c|c|c|c|}
\hline Location & Period of Sampling & $\mathrm{SO}_{4}$ & Org & $\mathrm{NH}_{4}$ & $\mathrm{NO}_{3}$ & $\mathrm{BC}$ & $\mathrm{CO}$ & $\mathrm{Org} / \mathrm{SO}_{4}$ & Criteria $^{b}$ \\
\hline North Pacific, Trindad Head, California ${ }^{\mathrm{c}}$ & Apr-May 02 & 0.93 & 0.38 & 0.2 & 0.09 & & & 0.41 & 7 \\
\hline $\begin{array}{l}\text { North Pacific, Ocean Station Papa } \\
\left(50.0^{\circ} \mathrm{N}, 145.0^{\circ} \mathrm{W}\right)^{\mathrm{d}}\end{array}$ & Jul 02 & 0.74 & 0.3 & 0.2 & 0.03 & & & 0.41 & 2 \\
\hline North Atlantic, Mace Head, Ireland ${ }^{\mathrm{e}}$ & Apr-Jun, Sep-Oct 02 & 0.26 & 0.91 & 0.1 & 0.02 & 20 & 130 & 3.5 & $1,2,6$ \\
\hline Ace-Asia, R/V Ron Brown ${ }^{\mathrm{f}}$ & Apr 02 & 0.25 & 0.31 & 0.07 & $<0.01$ & & & 1.2 & 2 \\
\hline North Pacific, Seattle, Washington ${ }^{\mathrm{g}}$ & Apr 06 & 0.52 & 0.15 & 0.16 & 0.02 & & & 0.2 & \\
\hline South Atlantic, R/V Marion Dufresne & Jan-Mar 07 & & & & & & & & \\
\hline \multirow[t]{3}{*}{$\left(20-60^{\circ} \mathrm{S}, 70^{\circ} \mathrm{W}-60^{\circ} \mathrm{E}\right)^{\mathrm{h}}$} & "Clean Atlantic" & & 0.18 & 0.03 & 0.06 & $<0.01$ & & 0.17 & 2 \\
\hline & "Antarctic" & & 0.31 & 0.02 & 0.05 & 0.01 & & 0.06 & \\
\hline & "Bloom" & & 0.21 & 0.32 & 0.07 & 0.02 & & 1.5 & \\
\hline Southeast Pacific, R/V Ron Brown ${ }^{\mathrm{i}}$ & Oct-Nov 08 & 0.67 & 0.1 & & $<0.2$ & & & 0.15 & 5,6 \\
\hline Southeast Pacific, VOCALS ${ }^{j}$ & Oct-Nov 08 & 0.52 & 0.10 & 0.06 & $<0.01$ & 10 & 60.4 & 0.19 & 3,4 \\
\hline clean MBL current study ${ }^{\mathrm{k}}$ & & 0.17 & 0.02 & $<0.01$ & $<0.01$ & 2.0 & 57.1 & 0.1 & \\
\hline natural MBL current study ${ }^{1}$ & & 0.20 & 0.02 & $<0.01$ & $<0.01$ & $<1.0$ & 56.8 & 0.1 & \\
\hline Central Pacific, $\mathrm{TAO}^{\mathrm{j}, \mathrm{m}}$ & Aug-Sep 09 & 0.79 & 0.07 & 0.1 & $<0.01$ & & & 0.08 & 6 \\
\hline
\end{tabular}

${ }^{a}$ All concentrations are in $\mu \mathrm{g} \mathrm{m}^{-3}$ except BC $\left(\mathrm{ng} \mathrm{m}^{-3}\right)$ and $\mathrm{CO}(\mathrm{ppb}){ }^{\mathrm{b}}$ abbreviations for clean air criteria: $1=\mathrm{Clean}$ air sector, $2=\mathrm{Air}$ Mass Back Trajectories, $3=\mathrm{BC}$ threshold, $4=\mathrm{CO}$ threshold, $5=$ radon, 6 = particle number concentration, 7 = Volatile Organic Carbon (VOC) tracers; ${ }^{\mathrm{c}}$ Allen et al. (2004); ${ }^{\mathrm{d}}$ Phinney et al. (2006); ${ }^{\mathrm{e}}$ Cavalli et al. (2004); ${ }^{\mathrm{f}}$ Quinn et al. (2004); ${ }^{\mathrm{g}}$ IMPEX*, ${ }^{\mathrm{h}}$ Zorn et al. (2008); ${ }^{\mathrm{i}}$ Hawkins et al. (2010); ${ }^{\mathrm{j}}$ current study; ${ }^{\mathrm{k}}$ data restricted to $\mathrm{BC}<4.5 \mathrm{ng} \mathrm{m}^{-3}, \mathrm{CO}<61 \mathrm{ppb} ;{ }^{1}$ data restricted to BC $<1.8 \mathrm{ng}$ $\mathrm{m}^{-3}, \mathrm{CO}<56 \mathrm{ppb} ;{ }^{\mathrm{m}} \mathrm{CN}<700 \mathrm{~cm}^{-3}$.

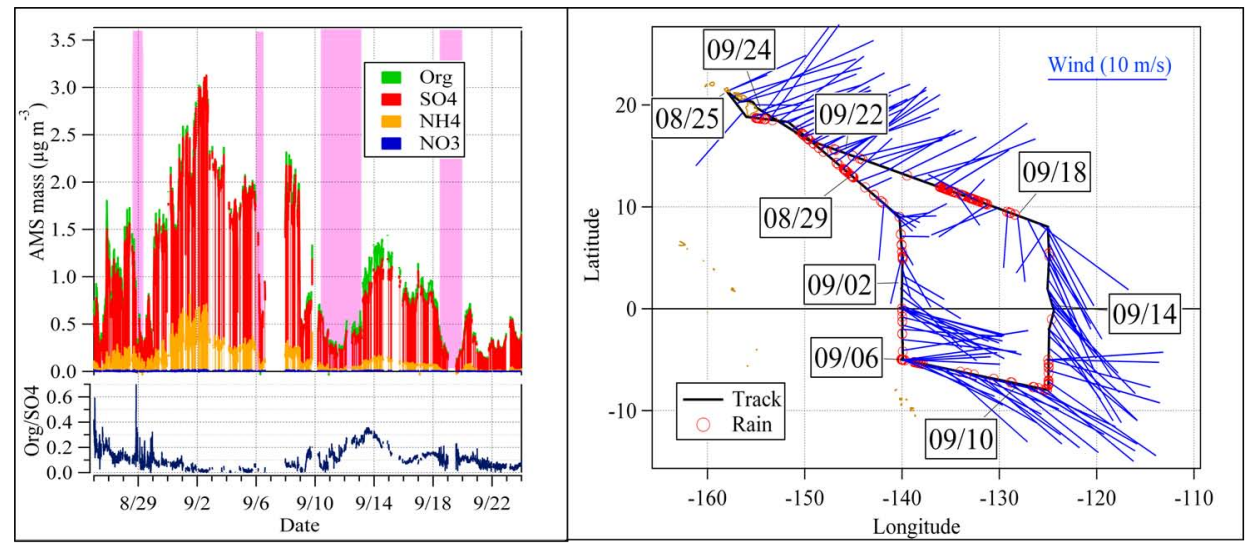

Fig. 3. (Left) Time series of AMS Org, $\mathrm{SO}_{4}, \mathrm{NH}_{4}, \mathrm{NO}_{3}$ and $\mathrm{Org} / \mathrm{SO}_{4}$ for TAO 2009 cruise. Shading indicates rain events; (Right) Cruise track with date tags, rain events, and wind direction (blue lines point from ship location into the wind). Length of wind line is proportional to the wind speed (see scale).

\section{Discussion}

\subsection{Isolating marine organic aerosol over the Southeast Pacific}

Both $\mathrm{CO}$ and $\mathrm{BC}$ can be used as tracers for combustion, though $\mathrm{BC}$ is more directly useful. Particulate species such as $\mathrm{BC}$ and Org are removed from the atmosphere by precipitation but $\mathrm{CO}$ is not. $\mathrm{CO}$ is only slowly removed by reaction with $\mathrm{OH}$ with an e-folding time of about 1-2 months (Jaffe et al., 1997) in the tropics and over a year in high latitudes during the winter (Staudt et al., 2001). In addition, CO has a fairly uniformly distributed background source from oxidation of methane and other organic vapors, which can be a significant fraction of total concentrations. To use it as a combustion tracer one must calculate deviations from background levels, while the presence of any $\mathrm{BC}$ at all indicates the presence of combustion aerosol. Nevertheless, CO measurements have been historically available and remain useful as pollution tracers.

The Southern Hemisphere has lower background levels of $\mathrm{CO}$ and $\mathrm{BC}$ than the Northern Hemisphere, where there is 


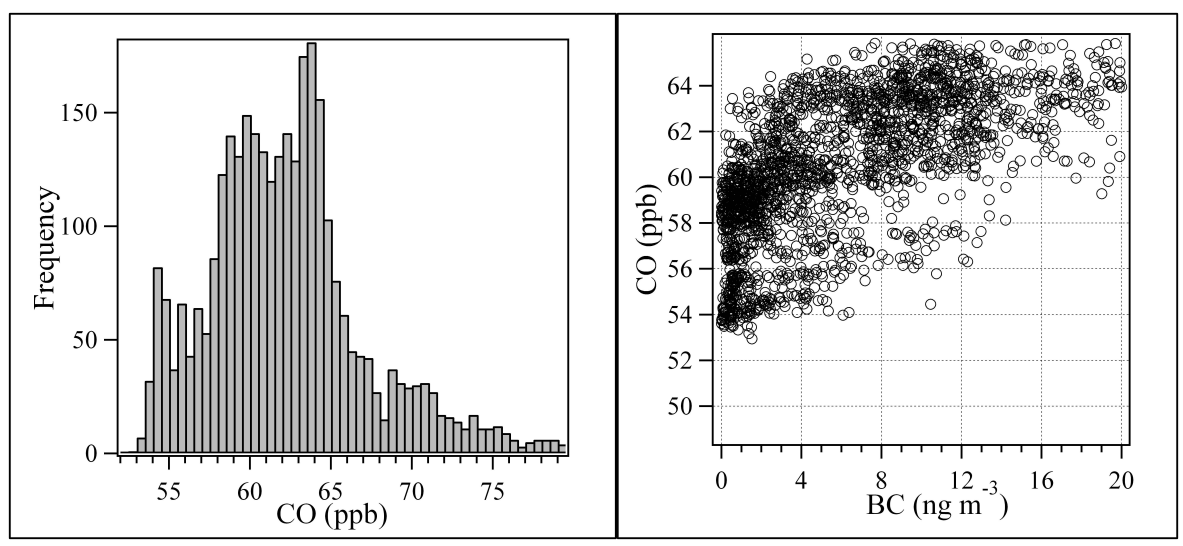

Fig. 4. (Left) Histogram of MBL CO concentrations during VOCALS; (Right) CO versus BC for VOCALS MBL.

more land mass, more human population, and more combustion. This should make it easier to find instances where continental Org are dwarfed by marine sources. Histograms of $\mathrm{CO}$ in the VOCALS MBL (Fig. 4) reveal two modes that occur below and above $61 \mathrm{ppb}$. A plot of MBL CO versus BC (Fig. 4) indicates that when BC approaches zero (e.g. no combustion aerosol), $\mathrm{CO}$ values range from $\sim 53-61 \mathrm{ppb}$, another indication that this $\mathrm{CO}$ value might represent the upper limit of background conditions in the SEP.

Trajectory analysis (Allen et al., 2011) indicates coastal zone trajectories (those initiated at $72^{\circ} \mathrm{W}$ ) are seen to consistently pass over the continental and coastal landmass and have mean $\mathrm{CO}$ values of $74 \mathrm{ppb}$ with lower and upper deciles ranging from 68 to $80 \mathrm{ppb}$, respectively. Trajectories initiated further offshore (i.e. at $76^{\circ} \mathrm{W}$ and $85^{\circ} \mathrm{W}$ ) demonstrate that land contact is made only in some trajectories, while others have not passed over land at all in at least the past five days. Mean $\mathrm{CO}$ values for the further offshore trajectories are $63 \mathrm{ppb}$, with an inter-quartile range of $2 \mathrm{ppb}$ (Figs. 4 and 5 in Allen et al., 2011). The Allen et al. (2011) trajectory analysis provides further justification that a background $\mathrm{CO}$ concentration of $61 \mathrm{ppb}$ is a reasonable background threshold in the SEP region.

A BC concentration of $4.5 \mathrm{ng} \mathrm{m}^{-3}$ was chosen as the BC threshold because it represents a rounded value of the average $\mathrm{BC}$ concentration associated with the low $\mathrm{CO}$ mode $(\mathrm{CO}<61 \mathrm{ppb})$ (actual average was $4.09 \pm 4.75 \mathrm{ng} \mathrm{m}^{-3}$ ). Therefore, $\mathrm{CO}<61 \mathrm{ppb}$ and $\mathrm{BC}<4.5 \mathrm{ng} \mathrm{m}^{-3}$ were the thresholds selected with which to characterize background conditions for the SEP.

Org vs. $\mathrm{BC}$ and $\mathrm{SO}_{4}$ vs. $\mathrm{BC}$, as well as $\mathrm{CO}$ in the VOCALS MBL are plotted in Fig. 5. Figure 5a shows Org vs. $\mathrm{BC}$ and Fig. 5b shows the $\mathrm{SO}_{4}$ vs. $\mathrm{BC}$ relationships for the free troposphere (FT) and MBL, all colored by CO. Figure $5 \mathrm{c}$ shows the strong relationship between Org and $\mathrm{BC}$ for $\mathrm{CO}<61 \mathrm{ppb}$. The regression has an intercept of 0 , and a $R^{2}$ value of 0.66 , suggesting a significant linear relation- ship and a common combustion source even for these low $\mathrm{CO}$ values. This strongly suggests that even at the lowest pollution levels we experienced, most of the Org was not of marine origin. Thus we conclude that in this region there is no threshold value for "clean" air below which pollution can be dismissed.

A similar relation between $\mathrm{BC}$ and $\mathrm{SO}_{4}$ is not seen, as evident by the poorer correlation $\left(r^{2}=0.46\right)$ and non-zero intercept between $\mathrm{SO}_{4}$ and $\mathrm{BC}$ over this same range (Fig. $5 \mathrm{~d}$ ). Residual $\mathrm{SO}_{4}$ as $\mathrm{BC}$ mass goes to zero is expected for clean background marine air, since $\mathrm{SO}_{4}$ has a known and welldocumented oceanic source (Andreae and Barnard, 1984; Andreae and Raemdonck, 1983; Cline and Bates, 1983). Visual inspection of Fig. 5d suggests that at concentrations of $\mathrm{BC}$ mass $<1.8 \mathrm{ng} \mathrm{m}^{-3}$ there is no relationship between $\mathrm{SO}_{4}$ and $\mathrm{BC}$. This $\mathrm{SO}_{4}$ is likely to be of marine origin, so any correlation with Org may represent Org with a similar marine origin. We limited $\mathrm{CO}$ to lower and lower concentrations until the low $\mathrm{CO}$ branch of the $\mathrm{SO}_{4}$ vs. $\mathrm{BC}$ relationship was highlighted. The data were reduced at a $\mathrm{CO}$ concentration of $56 \mathrm{ppb}$. For data with $\mathrm{CO}<56 \mathrm{ppb}, \mathrm{SO}_{4}$ varies from $0.05-0.5 \mu \mathrm{g} \mathrm{m}^{-3}$ (average $0.14 \pm 0.11$ ) while $\mathrm{CO}$ and $\mathrm{BC}$ vary little: $\mathrm{CO}$ varies from $52.9-55.9 \mathrm{ppb}$ with an average of $54.6 \pm 0.7 \mathrm{ppb}$, and BC mass varies from $0.0-2.0 \mathrm{ng} \mathrm{m}^{-3}$ with an average of $0.8 \pm 0.5 \mathrm{ng} \mathrm{m}^{-3}$. The relationship between $\mathrm{SO}_{4}$ and Org for cases with $\mathrm{CO}<56 \mathrm{ppb}$ is shown in Fig. 6. Values of Org and $\mathrm{SO}_{4}$ were then bin-averaged for every 0.05 increment of $\mathrm{SO}_{4}$, and are superimposed on the one-minute data from Fig. 5 with $1 \sigma$ error bars. A linear fit to the raw data suggests a relationship between Org and $\mathrm{SO}_{4}$, with a slope of $0.08 \pm 0.02$, possibly indicative of an oceanic source for this Org.

\subsection{Comparisons with other studies of marine aerosol}

Under the clean criteria $(\mathrm{CO}<56 \mathrm{ppb}$ and $\mathrm{BC}$ mass $<1.8 \mathrm{ng} \mathrm{m}^{-3}$ ), designed to isolate marine sulfate aerosol, Org constitutes only $6 \%$ of total submicron, 


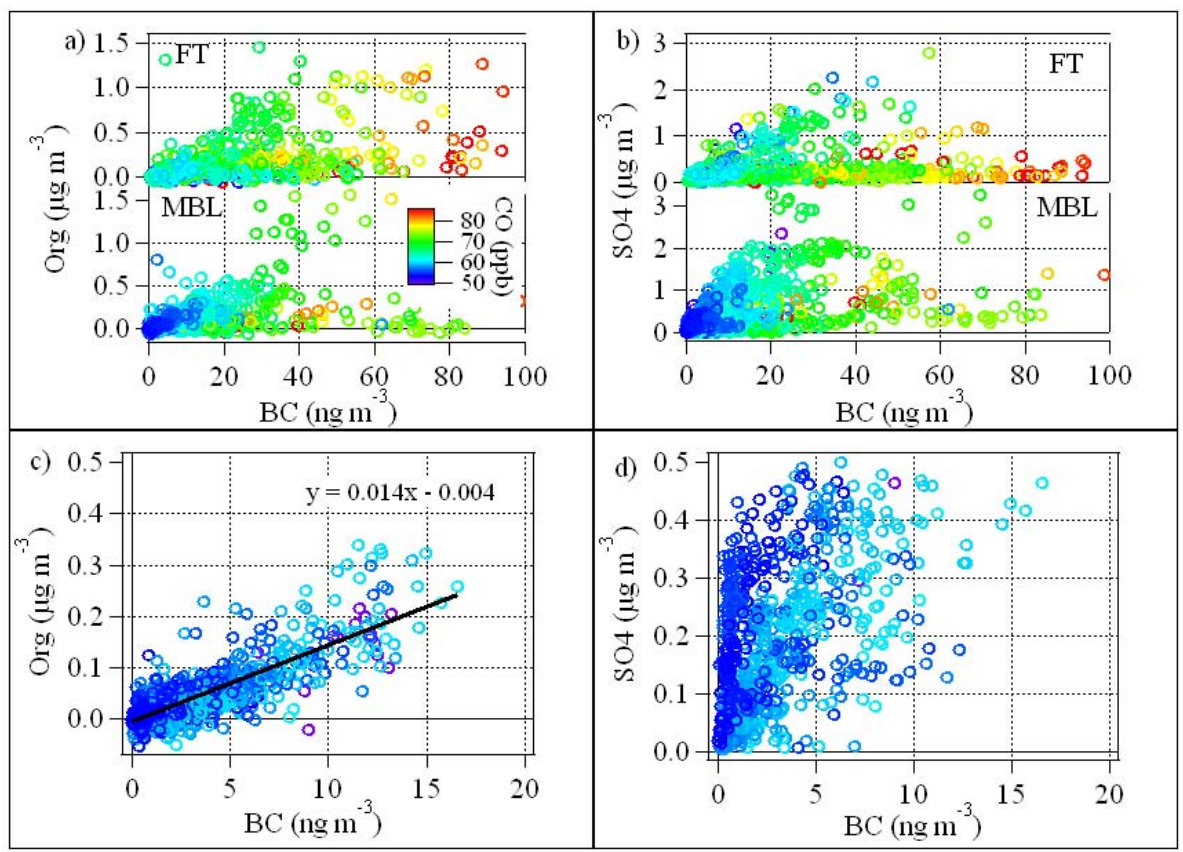

Fig. 5. (a) Org vs. BC mass, colored by $\mathrm{CO}$, both above (FT) and below (MBL) the inversion, (b) $\mathrm{SO}_{4}$ vs. $\mathrm{BC}$ mass, colored by $\mathrm{CO}$, and (c) Org and (d) $\mathrm{SO}_{4}$ vs. BC mass under $0.02 \mu \mathrm{g} \mathrm{m}^{-3}$ and $\mathrm{CO}$ less than $61 \mathrm{ppb}$.

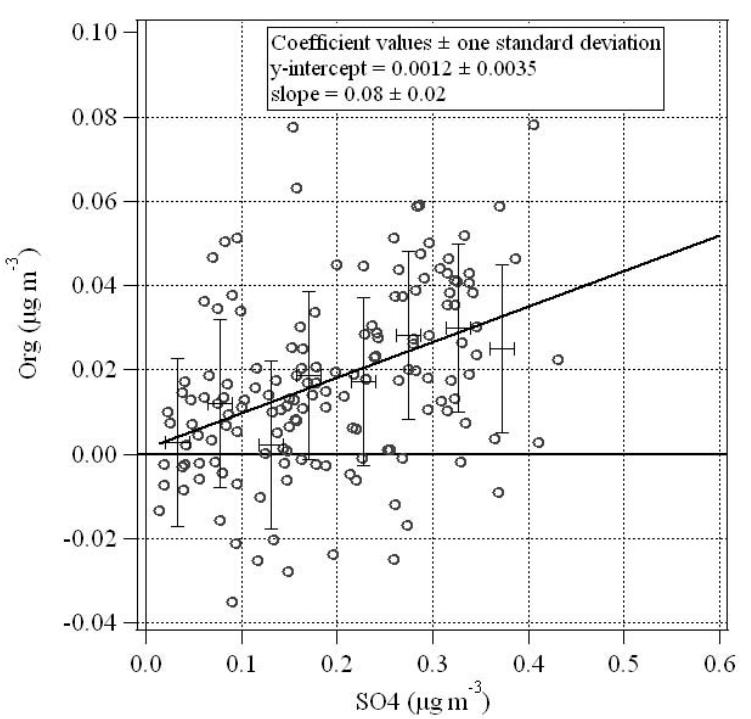

Fig. 6. Natural Org vs. $\mathrm{SO}_{4}$ (e.g. Org vs. $\mathrm{SO}_{4}$ for cases when $\mathrm{CO}<56 \mathrm{ppb}$ and $\mathrm{BC}$ mass $<1.8 \mathrm{ng} \mathrm{m}^{-3}$ ), one minute and binaveraged data.

non-refractory aerosol mass, while $\mathrm{SO}_{4}$ constitutes $87 \%$ of the total submicron non-refractory mass in the MBL. These results are up to $50 \%$ lower than other studies in the tropics and subtropics and far smaller than those reported for high latitudes and phytoplankton blooms (Fig. 1) which find Org to make up $25-40 \%$ of the total submicron non-refractory mass, and even up to $77 \%$ in North Atlantic aerosols (O’Dowd and de Leeuw, 2007).

Above cloud air in the FT often has higher concentrations of Org, BC, and $\mathrm{CO}$ than below cloud, but lower $\mathrm{SO}_{4}$ concentrations (Fig. 5a and b). Entrainment evident in this region (Bretherton et al., 2010) would therefore raise concentrations of Org and $\mathrm{BC}$ in the $\mathrm{MBL}$ while lowering $\mathrm{SO}_{4}$ by dilution. Furthermore, the range of relationships evident between $\mathrm{OC}$ and $\mathrm{BC}$ in the FT in Fig. 5a suggest the involvement of variable sources and aerosol removal processes.

The data discussed above and approximate slopes of the Org/SO $\mathrm{SO}_{4}$ ratio are drawn in Fig. 7 along with slopes included as visual representation of the relationships found from various studies that all focused on clean marine aerosols: Trinidad Head (TH), Mace Head (MH), VOCALS Ron Brown (RB), Ace-Asia (AA), IMPEX (IMP) and Ocean Station Papa (OSP). The plot also includes Org vs. $\mathrm{SO}_{4}$ data for the entire cruise (100 min averaged data), as well as VOCALS data (10 min, or leg-averaged, data). The TAO and VOCALS Org/SO $\mathrm{SO}_{4}$ data shows a considerable fraction of the measurements lie on or near to a line with a slope $\sim 0.1$ (TAO and VOC in Fig. 7). The before mentioned excursions from the TAO cruise-average $\mathrm{Org} / \mathrm{SO}_{4}$ ratio of 0.08 are indicated by TAO* in Fig. 7. VOCALS FT data (VOC FT), where the Org/ $\mathrm{SO}_{4}$ is significantly higher, is also plotted and reveals the potential to increase MBL values of $\mathrm{Org} / \mathrm{SO}_{4}$ through entrainment. 


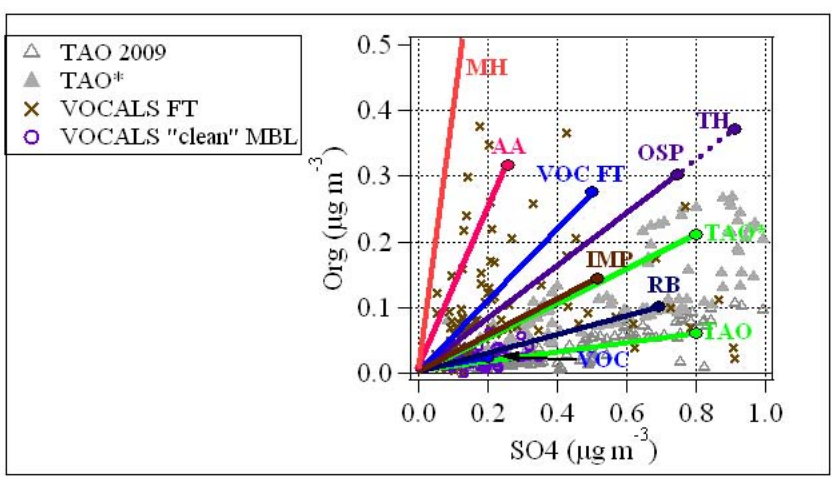

Fig. 7. AMS organics (Org) versus sulfate $\left(\mathrm{SO}_{4}\right)$ during TAO 2009 cruise, VOCALS “clean” MBL (VOC), and VOC FT. Also shown are approximate implicit slopes for the $\mathrm{Org} / \mathrm{SO}_{4}$ relationship from Trinidad Head (TH), Mace Head (MH), Ace-Asia (AA), IMPEX (IMP), Ocean Station Papa (OSP), and VOCALS Ron Brown (RB). Average reported clean values are shown as filled, colored circles, and the line drawn from the origin to the reported average is the implicit slope. Excursions from the TAO average $\mathrm{Org} / \mathrm{SO}_{4}$ of 0.08 are indicated as TAO*.

\subsubsection{Comparisons with shipboard VOCALS data}

It is striking that at the same time and place, the Ron Brown found higher Org concentrations, and thus a higher $\mathrm{Org} / \mathrm{SO}_{4}$ ratio (Sect. 3.1, Hawkins et al., 2010). Unfortunately, incompatible instrumentation made it hard to do direct comparisons. The C-130 lacked the radon $(\mathrm{Rn})$ measurements used aboard the ship to detect continental influence and the ship lacked CO and SP2 measurements, so a common definition of clean air cannot be made. On the Ron Brown Rn was used to classify roughly $40 \%$ of the cruise as having Marine Air Mass (MAM) characteristics. However, results from their PMF analysis showed that approximately $75 \%$ of the OM during those periods fit their combustion factor rather than the marine factor. Therefore of their average MAM OM of $0.4 \mu \mathrm{g} \mathrm{m}^{-3}$ determined from FTIR, only about $0.1 \mu \mathrm{g} \mathrm{m}^{-3}$ is of potential marine origin. It is not clear what fraction of the $\mathrm{SO}_{4}$ is marine, so their $\mathrm{Org} / \mathrm{SO}_{4}$ ratio from marine sources is between 0.15 and 0.6. The lower end of their range is still $>50 \%$ above our estimate of 0.08 . Differences in the campaign $\mathrm{Org} / \mathrm{SO}_{4}$ ratios between the $\mathrm{C}-130$ and Ron Brown are shown in Fig. 8a and b as histograms of the ratio. Ron Brown AMS Org were reported as 0 for concentrations below their instrument's detection limit $\left(<0.16 \mu \mathrm{g} \mathrm{m}^{-3}\right)$, biasing average concentrations low. In order to decrease this bias, for the purpose of this comparison, Org concentrations below instrument detection limits were replaced with half of that detection limit $\left(0.08 \mu \mathrm{g} \mathrm{m}^{-3}\right)$. For the unrestricted cases, i.e., no clean air selection criteria applied, the Ron Brown observed higher $\mathrm{Org} / \mathrm{SO}_{4}$ ratios (geometric mean and geometric standard deviation of $0.28 \pm 2.11)$ than the $\mathrm{C}-130(0.18 \pm 2.08)$. When $\mathrm{CN}$ is used as a clean air indicator, and is restricted to cases $\mathrm{CN}<700 \mathrm{~cm}^{-3}$ and $\mathrm{CN}<350 \mathrm{~cm}^{-3}$, the frequency distributions of $\mathrm{Org} / \mathrm{SO}_{4}$ for the two platforms remain consistent with the unrestricted cases: Ron Brown geometric means and standard deviations for $\mathrm{CN}<700 \mathrm{~cm}^{-3}$ and $<350 \mathrm{~cm}^{-3}$ are $0.28 \pm 2.08$ and $0.27 \pm 1.95$, respectively. For VOCALS geometric means and standard deviations for $\mathrm{CN}<700 \mathrm{~cm}^{-3}$ and $<350 \mathrm{~cm}^{-3}$ are $0.18 \pm 2.75$ and $0.19 \pm 2.95$, respectively. Although $\mathrm{CN}$ is not as direct an indicator of pollution as the use of $\mathrm{CO}$ and $\mathrm{BC}$, it was the only common measurement across the sampling platforms. The consistently higher $\mathrm{Org} / \mathrm{SO}_{4}$ values for the Ron Brown suggest that during VOCALS, the Ron Brown was in contact with more continentally influenced air than the C-130, and therefore observed higher absolute and relative concentrations of Org throughout the campaign.

We think a dramatic under-sampling of OM by the AMS during VOCALS is unlikely, but there are a few mechanisms by which it could occur. Hawkins et al. (2010) found their AMS had a particularly low CE for Org in the VOCALS region. Measurements of Org from FTIR showed 2.4 times as much as their AMS (at $\mathrm{CE}=1$, which worked well for $\mathrm{SO}_{4}$ and $\mathrm{NH}_{4}$ ). Much of this difference in Org correlated with dust elements, so they attributed low CE to refractory Org found on submicron dust particles originating from South America. As dust particles are of continental origin, low CE values associated with Org on dust would not impact the results of our study.

Another possible source of error that might bias the absolute values of Org low is through application of CE correction values to the data. In the unlikely condition of completely externally mixed aerosol where Org are collected with $\mathrm{CE} \approx 0.5$ and the $\mathrm{SO}_{4}$ is not neutralized, and is therefore being collected with $\mathrm{CE}=1$ the resulting $\mathrm{Org} / \mathrm{SO}_{4}$ would be a factor of 2 low. However, the $\mathrm{CE}$ we applied lies between 0.5 and 0.7 $64 \%$ of the time. Therefore, externally mixed Org might be underestimated by up to $30 \%$. A third possibility for under sampling of Org by our AMS could be the inlet efficiency. Calibrations have shown that there are significant particle losses by our AMS inlet at particle diameters greater than $600 \mathrm{~nm}$, vacuum aerodynamic diameter. Hence, a significant Org fraction present on coarse sea-salt remains possible, although prior measurements of size resolved OM in marine aerosol find over $90 \%$ concentrated in sizes well resolved by our AMS (Fig. 2; O'Dowd et al., 2004; Keene et al., 2007). Plots and regression (not shown) of Org vs. OPC coarse nonvolatile mass (the latter a sea-salt surrogate in the MBL) also revealed no evidence of a relation between the OM concentrations measured by our AMS and sea-salt concentrations.

Some organics are not volatile at the $600^{\circ} \mathrm{C}$ temperature of the AMS heater. It is conceivable that the AMS cannot detect some primary marine organics.

While the issues raised in the above paragraphs show a possibility that the AMS samples marine organics inefficiently, previous studies in laboratories (Matthew et al., 2008), in urban pollution (Middlebrook et al., 2011) and in 


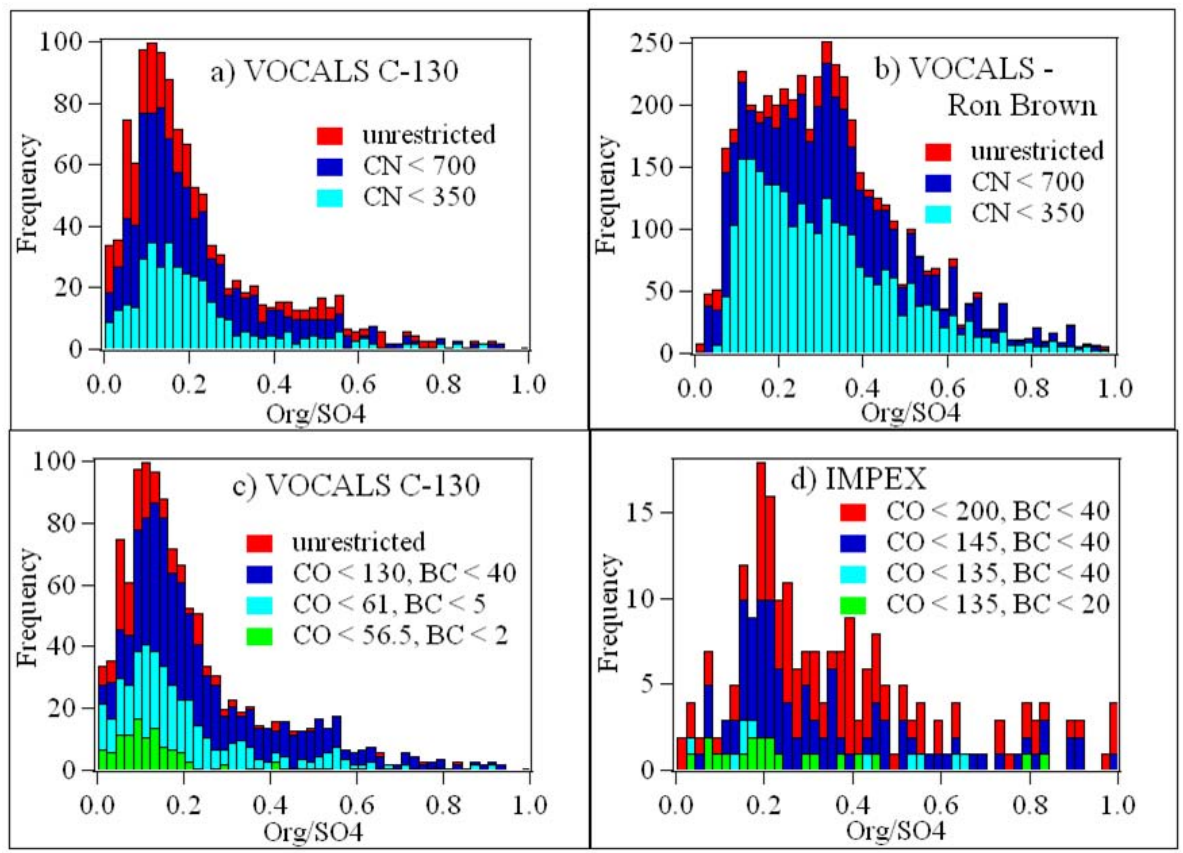

Fig. 8. Histograms of $\mathrm{Org} / \mathrm{SO}_{4}$ from different platforms and campaigns, restricted to varying clean air criteria. Units are as follows: $\mathrm{CN}$ $\left(\mathrm{cm}^{-3}\right), \mathrm{CO}(\mathrm{ppb})$, and $\mathrm{BC}\left(\mathrm{ng} \mathrm{m}^{-3}\right)$.

clean conditions in the far north Atlantic and Arctic Oceans (Russell et al., 2010) all demonstrated near 1:1 agreement between AMS Org and other OM measurements after the application of CE corrections based on sulfate neutralization. It appears very unlikely that our $\mathrm{Org} / \mathrm{SO}_{4}$ values are low by a factor of 2 .

One issue that remains unresolved is that Keene et al. (2007) found an order of magnitude higher OM $\left(\sim 0.1 \mu \mathrm{g} \mathrm{m}^{-3}\right)$ than our values when bubbling air through seawater from Bermuda with dissolved OM concentrations typical of oligotrophic areas. Their OM was enriched in exactly the particle size range the AMS samples well. It is not clear why their numbers are so much higher. We look forward to other experiments of this type to see whether the disagreement persists.

\subsubsection{IMPEX}

Figure $8 \mathrm{c}$ shows the $\mathrm{Org} / \mathrm{SO}_{4}$ histograms during VOCALS, but constrained to clean air cases using varying, and increasingly more restrictive, concentrations of $\mathrm{BC}$ and $\mathrm{CO}$. When VOCALS C-130 data are constrained to $\mathrm{CO}<61 \mathrm{ppb}$, $\mathrm{BC}<4.5 \mathrm{ng} \mathrm{m}^{-3}$ the geometric mean and standard deviation decrease from $0.18 \pm 2.08$ (for unrestricted cases) to $0.15 \pm 3.08$. Further restriction, to $\mathrm{CO}<56 \mathrm{ppb}$ and $\mathrm{BC}<1.8 \mathrm{ng} \mathrm{m}^{-3}$, yields a geometric mean of $0.10 \pm 2.85$. Histograms of $\mathrm{Org} / \mathrm{SO}_{4}$ ratios from another campaign (IMPEX), in which an identical SP2 and AMS were operated, are shown in Fig. 8d. The Northern Hemisphere is generally more polluted, and therefore $\mathrm{CO}$ and $\mathrm{BC}$ concentrations were not at the low levels observed in the Southeast Pacific. As in VOCALS, the frequency distributions of the $\mathrm{Org} / \mathrm{SO}_{4}$ ratio are shifted to lower values (lower geometric means) as the clean thresholds of $\mathrm{BC}$ and $\mathrm{CO}$ concentrations are lowered, as opposed to the use of $\mathrm{CN}$ to restrict clean air cases as discussed above. At the cleanest IMPEX levels $(\mathrm{CO}<135 \mathrm{ppb}$ and $\mathrm{BC}<20 \mathrm{ng} \mathrm{m}^{-3}$ ) the geometric mean of the $\mathrm{Org} / \mathrm{SO}_{4}$ ratio is $0.17 \pm 1.78$. Unfortunately, the clean IMPEX data suffers from poor statistics, as the main objective of the campaign was measure pollution transport across the North $\mathrm{Pa}$ cific so cases of clean air were sparse.

\subsubsection{Patterns of $\mathrm{Org} / \mathrm{SO}_{4}$}

Our results are in broad agreement with the established pattern that $\mathrm{Org} / \mathrm{SO}_{4}$ is lower in remote oligotrophic tropical and subtropical regions than at high latitude, productive regions (see Fig. 1 and Table 1). At 0.17 , the IMPEX ratio $\left(45^{\circ} \mathrm{N}\right)$ exceeds that of VOCALS $\left(0.08\right.$ at $\left.20^{\circ} \mathrm{S}\right)$ and TAO2009 $(0.09$ at the Equator). If we had an SP2 on the TAO cruise, we would probably have found that some of the Org was of combustion origin, lowering Org/SO $\mathrm{SO}_{4}$ to or below the VOCALS ratio. This pattern is very likely due to the different plankton communities.

While our latitudinal pattern agrees with earlier studies, the $\mathrm{Org} / \mathrm{SO}_{4}$ values we report here are significantly below the other studies mentioned in Table 1 . The obvious reason is that we could use the fast response of the SP2 to establish the 
presence of even minimal $\mathrm{BC}$ influence. That turned out to be substantial, with combustion-related Org comprising roughly $2 / 3$ rds of total Org even at BC $<15 \mathrm{ng} \mathrm{m}^{-3}$ (Fig. 5c). Other studies in Table 1 characterized aerosol under relatively clean conditions, but did not attempt to eliminate all pollution influence, which would be very difficult to do with long integrating periods like those necessary in filter sampling. If we neglected $\mathrm{BC}<20 \mathrm{ng} \mathrm{m}^{-3}$, our $\mathrm{Org} / \mathrm{SO}_{4}$ during VOCALS would be 0.19 , in agreement with the Ron Brown VOCALS data, the "clean Atlantic" data of Zorn et al. (2008), and just a factor of 2 below the North Pacific sampling sites, which are subject to cross-Pacific transport of Asian aerosol (Table 1).

Our $\mathrm{Org} / \mathrm{SO}_{4}$ values are far below those from ACE-Asia and Mace Head. While the presence of significant BC at the latter site indicates some contamination by combustion aerosols, much of that difference is undoubtedly due to different plankton populations: the isotope analyses of Ceburnis et al. (2011) and the correlations with chlorophyll- $a$ in O'Dowd et al. (2008) demonstrate that a large fraction of $\mathrm{OM}$ there is of marine origin.

There are some other differences between our sampling techniques and other projects that may be partly responsible for our lower $\mathrm{Org} / \mathrm{SO}_{4}$ values, though we have no reason to believe they are major effects. One such difference is that winds in the tropics are often weaker than those at high latitudes, perhaps limiting primary organic aerosol production. Roughly $7 \mathrm{~m} \mathrm{~s}^{-1}$ is required for whitecap formation, and wind speeds during the VOCALS clean periods ranged from $\sim 5$ to $13 \mathrm{~m} \mathrm{~s}^{-1}$. Whitecaps are plainly visible in onboard video recordings during these clean periods, but may be less common than at higher latitudes.

Not all measurements of Org compared in this study are equal. Some studies (O'Dowd et al., 2004; Cavalli et al., 2004; Quinn and Bates, 2003; Phinney et al., 2006) rely on filter-based measurements of OA. Filter measurements have significant biases, including negative artifacts from volatilization of particulate-phase organics from the filter surface, and positive artifacts from adsorption of gas-phase organics onto the filter (Turpin et al., 2000). There is also the issue of particle bounce off the collection substrate of an impactor stage during sampling, leading to inaccurate size classifications. Also, in order to convert total organic carbon (TOC) from bulk filter measurements to water soluble and insoluble organic carbon (e.g. Cavelli et al., 2004) and POM (e.g. Quinn and Bates, 2003), TOC measurements from filters are multiplied by a conversion factor that represents a ratio between molecular mass and carbon mass. Filter measurements do not, however, suffer from the potential refractory-organics or size-dependent losses as the AMS does. All of the above mentioned factors must be considered when comparing studies of OM measurements.

The same issue is true for the different methods of measuring black carbon. Filter-based techniques for measuring black carbon, such as with instruments as the aethelometer (as used in Cavelli et al., 2004), and the particle soot absorp- tion photometer (PSAP), use the decrease in light transmission through a filter as it becomes loaded with aerosol. This measure of aerosol light absorption is then related to total BC through formulas (Lack et al., 2008). Errors to filter-based instruments include deposit and filter matrix interactions that may change the physical and optical properties of the system, leading to inaccurate light absorption measurements, as well as the use of corrections which can alter the measured change in transmission, limiting accuracies to between 20 $30 \%$ (Bond et al., 1999; Virukkula et al., 2005; Weingartner et al., 2003). In addition, the PSAP suffers from positive artifacts that may result in higher than actual measurements of $\mathrm{BC}$, and facilitate the necessity to set a higher threshold for clean conditions. An arbitrarily higher threshold has additional implications for comparing BC measured by the PSAP to those measured by other methods (i.e. SP2).

\subsection{Org enrichment during the TAO cruise}

In order to explore the relation of the Org enhancement during the cruise (TAO* in Fig. 7) to possible ocean sources, eight-day composites of chlorophyll- $a$ concentration were produced using SeaWIFS (Sea-viewing Wide Field-of-viewSensor) Level 3 products provided by NASA/Goddard Space Flight Center (Ocean Color Web (http://oceancolor.gsfc. nasa.gov) accessed June 2010). Surface chlorophyll- $a$ concentrations do not indicate a significant increase in biological production for corresponding aerosol measurements on the western boundary of the cruise track (Fig. 9a), and the eastern edge of the cruise (Fig. 9b, 11 September to 15 September).

Fifteen-day Air Mass Back Trajectories (AMBTs) were performed using the National Oceanic and Atmospheric Administration's (NOAA) Hybrid Single-Particle Lagrangian Integrated Trajectory (HYSPLIT) model access via NOAA ARL READY website (http://www.arl.noaa.gov/ ready/hysplit4.html). Isentropic trajectories were run at 4 altitudes $(100 \mathrm{~m}, 1000 \mathrm{~m}, 1250 \mathrm{~m}$, and $1500 \mathrm{~m})$ using the GDAS meteorological dataset. The $100 \mathrm{~m}$ trajectory (red) origin was varied spatially by $1^{\circ}$ north, south, east, and west, in order to capture spatial variability in the model. Within this spatial variation the trajectories were consistent for approximately the first 6 days of the AMBT, after which the $100 \mathrm{~m}$ trajectories tended to diverge. For simplicity, only one of the $100 \mathrm{~m}$ trajectories is displayed in Fig. 9. Several sets of trajectories were run, half during the peak of the $\mathrm{Org} / \mathrm{SO}_{4}$ excursion on the eastern most edge of the cruise track, and half on the western edge of the cruise track, where Org/ $/ \mathrm{SO}_{4}$ is close to the cruise-average 0.08 value. However, for clarity, only two sets of trajectories are plotted in Fig. 9. Altitude profiles for the AMBTs are shown in Fig. 9c and d.

AMBTs from one day, chosen to represent the western edge of the cruise track (3 September), indicate that influencing air masses have (a) passed through the Inter-Tropical Convergence Zone (ITCZ), where convection and rainfall 


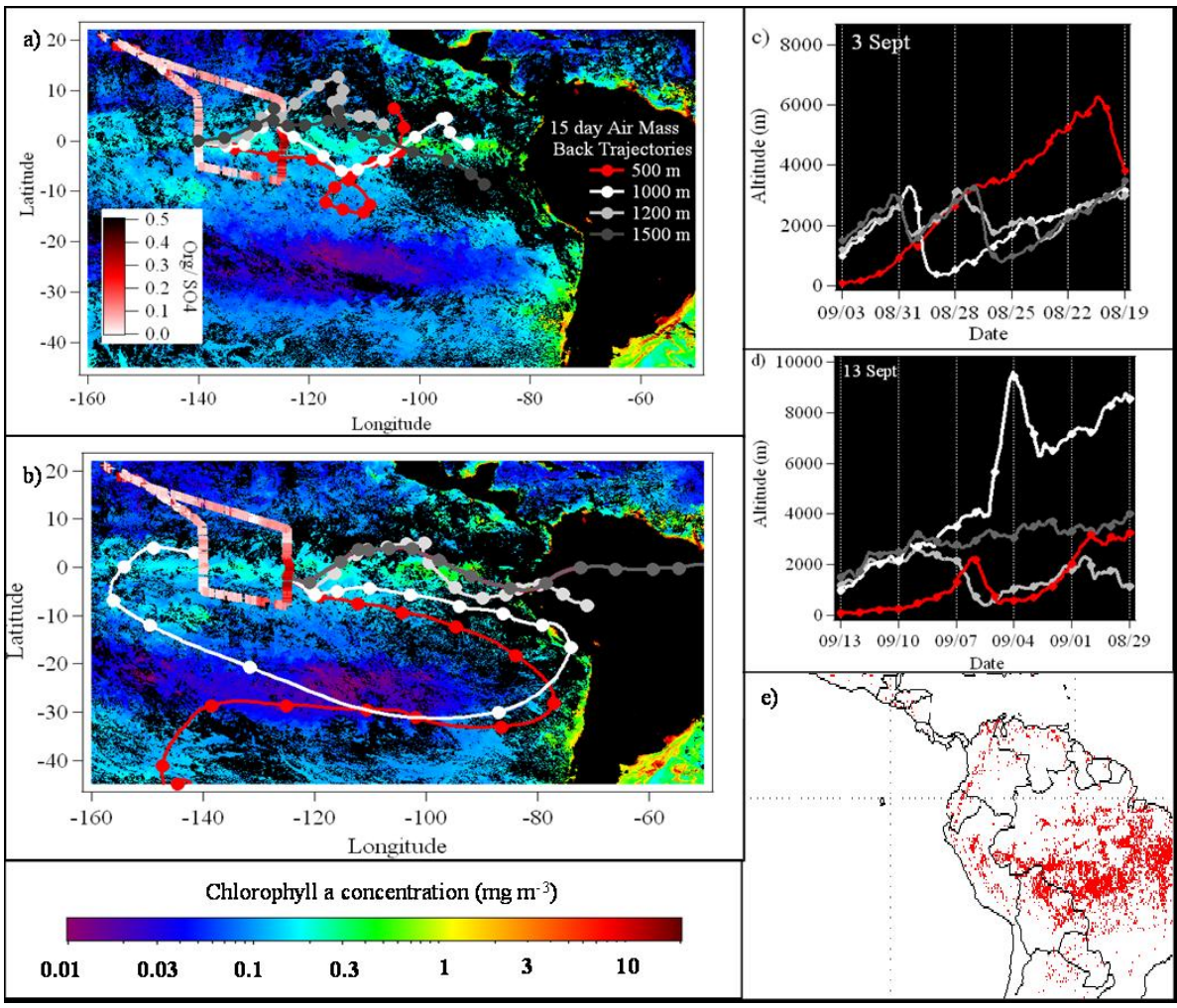

Fig. 9. SeaWIFS chlorophyll- $a 8$ day composite for periods (a) 29 August-5 September 2009 overlaid by AMBTs from 3 September 2009 and (b) 6 September-13 September 2009 overlaid by AMBTs from 13 September 2009. Cruise track is shown, colored by Org/SO 4 . AMBT altitude profiles are shown for (c) 3 September 2009 and (d) 13 September 2009. Altitude profiles are colored using the same legend as (a). Panel (e) biomass burning events from 1 September-8 September 2009 (FLAMBE').

could have removed particulate matter, and (b) spent the past 15 days over the ocean, with no indication of continental influence. The influence of ITCZ precipitation upon aerosol concentrations is clearly evident in Fig. 3 where they are reduced by up to a factor of four on 11 September and recover by 14 September. During the time period 12 September-14 September $\mathrm{SO}_{4}$ concentrations increase by a factor of 4 ranging from 0.25 to 0.95 , with an average $0.58 \pm 0.24 \mu \mathrm{g} \mathrm{m}^{-3}$, while the $\mathrm{Org} / \mathrm{SO}_{4}$ ratio ranges from 0.17 to 0.41 with an average of $0.28 \pm 0.04$. The relatively consistent $\mathrm{Org} / \mathrm{SO}_{4}$ ratio indicates no preferential removal of either species. All of the sets of high altitude trajectories (1000, 1200, and $1500 \mathrm{~m}$ ) during the peak in the $\mathrm{Org} / \mathrm{SO}_{4}$ ratio from 13 September indicate that air masses have had possible continental influence in the past 15 days (Fig. 9b). While one may question 15 day back trajectories we note that the stability of the prevailing flow makes trajectories less variable in this region than most and at typical wind speeds it takes 10 days or more to reach South America from Christmas Island.

As previously noted for our VOCALS data, biomass burning in South America serves as a potential source of Org to the FT, and data from the Fire Locating and Modeling of Burning Emissions (FLAMBE' (http://www.nrlmry.navy. mil/flambe/) accessed July 2010) indicates widespread fires in the Amazon at the beginning of September, approximately 1-2 weeks before sampling occurred (Fig. 9e). Levoglucosan is a chemical tracer for biomass burning, as it is formed during the pyrolysis of cellulose (Simoneit et al., 1998). Lee et al. (2010) found that the AMS peak at $m / z$ 60, more specifically $\mathrm{C}_{2} \mathrm{H}_{4} \mathrm{O}_{2}$, a fragment resulting from the breakdown of levoglucosan and other anhydrosugars, including mannosan, galactosan, arabinosan, and xylosan, is an even better indication of biomass burning than levoglucosan itself. However, Russell et al. (2010) has determined that marine Org in the North Atlantic are primarily carbohydrate-like, and also shows up at $m / z 60$ and 44 , so the AMS mass spectra cannot by themselves exclude marine sources of elevated Org.

Using the high resolution data analysis and elemental analysis package for the AMS (Aiken et al., 2008), $\mathrm{C}_{2} \mathrm{H}_{4} \mathrm{O}_{2}$ was identified and quantified by averaging the cruise data over $\sim 12 \mathrm{~h}$ periods. Figure 10 shows the fraction of $\mathrm{C}_{2} \mathrm{H}_{4} \mathrm{O}_{2}$ to total Org concentration, along with $12 \mathrm{~h}$ averaged $\mathrm{Org} / \mathrm{SO}_{4}$ overlaying the $10 \mathrm{~min} \mathrm{Org} / \mathrm{SO}_{4}$ from Fig. 3. Because the signal to noise level is lower for the $\mathrm{C}_{2} \mathrm{H}_{4} \mathrm{O}_{2}$ peak, error bars $(1 \sigma)$ are shown as well.

The $\mathrm{C}_{2} \mathrm{H}_{4} \mathrm{O}_{2}$ data are characterized by high errors due to low Org signal, therefore there is no statistical change in the $\mathrm{C}_{2} \mathrm{H}_{4} \mathrm{O}_{2} / \mathrm{Org}$ value during the $\mathrm{Org} / \mathrm{SO}_{4}$ excursion on the 13 


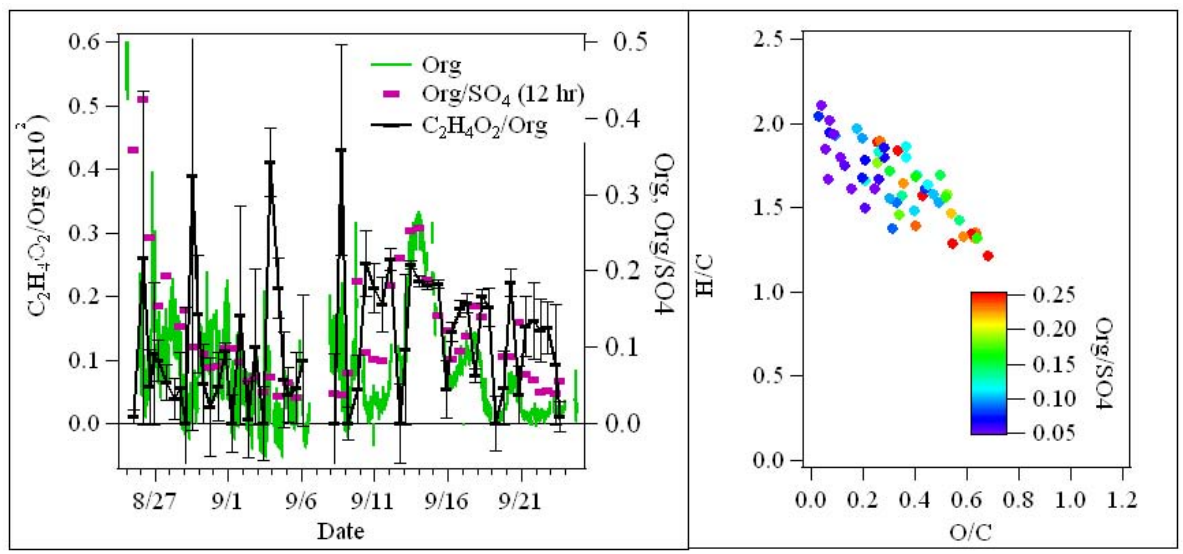

Fig. 10. (Left) Time series of Org (10 min average), Org/SO $\mathrm{SO}_{4}\left(12 \mathrm{~h}\right.$ average), and $\mathrm{C}_{2} \mathrm{H}_{4} \mathrm{O}_{2}(12 \mathrm{~h})$. One sigma errors for the data are indicated. (Right) $\mathrm{H} / \mathrm{C}$ vs. $\mathrm{O} / \mathrm{C}$ for the $12 \mathrm{~h}$ averaged data (Van Krevelen plot).

September. However, levoglucosan was detected at a groundsite in Paposo, Chile $\left(25.0^{\circ} \mathrm{S}, 70.5^{\circ} \mathrm{W}, 690 \mathrm{~m}\right.$ above mean sea level) during VOCALS (Chand et al., 2010). The prevailing wind at the ground-site in Paposo is southerly, representing a region upwind of the TAO cruise area. Trajectory and MODIS analysis suggested the biomass burning source for the levoglucosan during the Chand et al. study came from the Chilean lowlands, west of the Andes, in the latitude range $35-40^{\circ} \mathrm{S}$. While the detection and identification of the $\mathrm{C}_{2} \mathrm{H}_{4} \mathrm{O}_{2}$ fragment is consistent with both biomass burning and marine sources of Org, the trajectory analysis and lack of change in surface chlorophyll- $a$ concentrations suggests a biomass burning source for the increased Org concentrations during the 13 September $\mathrm{Org} / \mathrm{SO}_{4}$ excursion. Transport in the FT appears reasonable as a potential source of Org to the Central Pacific MBL, similar to what was observed during VOCALS, but unfortunately no above-cloud data is available during the TAO cruise. However, such transport in the FT over this equatorial region has been noted in other papers (Hsu et al., 1996; Kim and Newchurch, 1996).

Twelve hour averages of the elemental ratios $\mathrm{H} / \mathrm{C}$ versus $\mathrm{O} / \mathrm{C}$ are shown on a Van Krevelen plot (Heald et al., 2010) in Fig. 10 as well, and are colored by the $\mathrm{Org} / \mathrm{SO}_{4}$ ratio. Heald et al. (2010) showed that a Van Krevelen diagram provides an indication of the amount of aging an aerosol has undergone, i.e. the longer an aerosol is in the atmosphere, the more oxidized it will become, and the $\mathrm{H} / \mathrm{C}$ ratio will decrease while the $\mathrm{O} / \mathrm{C}$ ratio will increase (Heald et al., 2010). Figure 10 reveals the more aged aerosol during TAO to be generally associated with the higher $\mathrm{Org} / \mathrm{SO}_{4}$ ratio, indicating a non-local source for these aerosols. The lower values of $\mathrm{Org} / \mathrm{SO}_{4}$ are associated with higher $\mathrm{H} / \mathrm{C}$ and lower $\mathrm{O} / \mathrm{C}$, suggesting a more local, perhaps oceanic, source. However, Van Krevelen diagrams were developed to illustrate oxidation of hydrocarbon-like pollutants and it is not clear how well it applies to natural marine organics.

\subsection{Implications for modeling studies}

Modeling sea-spray aerosol, and the contribution of marine organic aerosol to global emissions, has been the subject of recent studies (Langmann et al., 2008; O'Dowd et al., 2008; Vignati et al., 2010). Several relationships have been used to relate water insoluble organic mass fraction to surface chlorophyll- $a$ concentrations upwind of the measurements. While modeling studies that use no marine OA contribution underestimate field observations of Org, those that employ the previously mentioned functions to extrapolate OA production globally often overestimate Org aerosol concentrations by a factor of 4 or 5 compared to observations (Lapina et al., 2011).

Under the cleanest conditions determined for each campaign the VOCALS, TAO, and IMPEX Org contributions to total submicron mass are $6 \%, 7 \%, 18 \%$, respectively. Monthly averaged chlorophyll- $a$ concentrations (from SeaWIFS) in surface water upwind of these study areas averaged $0.15,0.20$, and $0.5 \mathrm{mg} \mathrm{m}^{-3}$ for VOCALS, TAO, and IMPEX, respectively. If plotted along with the O'Dowd et al. (2008) data, the slope of the relationship from our data is similar to that established by Langmann et al. (2008) and Vignati et al. (2010), however our data points plot in the low percent Org mass $(0-20 \%)$, low chlorophyll- $a\left(0.15-0.2 \mathrm{mg} \mathrm{m}^{-3}\right)$ portion of the O'Dowd (2008) plot. Our data suggests a relationship that falls along the lower envelope of points in that plot and passes through the origin rather than having a significant intercept at zero chlorophyll- $a$. At first glance, a nonzero intercept is implausible: if there were no chlorophyll- $a$ then there should be no production of OM. A finite intercept suggests either a non-marine source or a more complicated relationship between productivity and OM emissions. Given the difficulties of connecting chlorophyll- $a$ to DMS concentrations (e.g. Bell et al., 2010), a complex relationship between chlorophyll- $a$ and other organics is perhaps to be expected but may not generalize easily across the globe. As a 
crude calculation, if a linear relationship that encompasses our data were used for models then the modeled Org percent mass for the mean global chlorophyll of $0.36 \mathrm{mg} \mathrm{m}^{-3}$ (Siegel et al., 2002) should drop by a factor of 2 , from $30 \%$ OM to values near $15 \% \mathrm{OM}$. That is approximately the conclusion arrived at in the recent parameterization paper by Lapina et al. (2011), which included the Ron Brown VOCALS data.

\section{Conclusions}

Our measurements in marine boundary layer air over the remote South Pacific during VOCALS revealed low Org concentration in marine aerosol with values that trended linearly with combustion derived $\mathrm{BC}$ mass concentrations down to values of $\mathrm{BC}<2 \mathrm{ng} \mathrm{m}^{-3}$. The slope indicates about 13 times as much Org mass is present as BC mass, a ratio consistent with biomass burning emissions (Reid et al., 2005). Data stratification to low concentrations of $\mathrm{BC}$ mass was made possible by the relatively rapid measurements of Org and BC made by an HR-ToF-AMS and an SP2. The significant relationship between Org and BC indicates that most of the Org was combustion related $\left(R^{2}=0.66, y=-0.004 \pm 0.002\right)$ even at very low $\mathrm{CO}$ and $\mathrm{BC}$ concentrations and raises questions about the appropriate choice of a clean threshold for BC to eliminate influences of combustion aerosol when characterizing background marine aerosol. The concept of establishing background conditions is insufficient; it is necessary to either demonstrate that the natural aerosols overwhelm the anthropogenic influences such that they can be ignored, or employ some technique to isolate marine from continental aerosols, such as the use of carbon isotopes (e.g. Ceburnis et al., 2011). Correlations of Org with $\mathrm{SO}_{4}$ at very low $\mathrm{BC}$ and $\mathrm{CO}$ concentrations suggest that marine $\mathrm{Org} / \mathrm{SO}_{4} \approx 0.08$ in this region. This conclusion is consistent with the TAO 2009 cruise, where only a small percentage of submicron nonrefractory aerosol mass is Org ( $\sim 6 \%$ for VOCALS, $\sim 7 \%$ for TAO). While the low values we found of $\mathrm{Org} / \mathrm{SO}_{4}$ due to marine sources is smaller than many studies from tropical and subtropical regions, those studies generally characterized the air during relatively clean periods; isolating marine from continental fractions was not feasible. Therefore, our conclusion that $\mathrm{OA}$ is only a small fraction of the aerosol over oligotrophic waters in the remote, clean, tropical Pacific is not inconsistent with earlier studies. While highly productive regions of the ocean are well documented as a major source of OA, Org may have a smaller role over the vast, relatively unproductive majority of the oceans. Data from IMPEX (average $\mathrm{Org} / \mathrm{SO}_{4} \approx 0.17$ ) in the eastern North Pacific were limited, but consistent with VOCALS and TAO, where the mode $\mathrm{Org} / \mathrm{SO}_{4}$ ratios decreased to smaller values as clean air criteria were restricted to lower $\mathrm{BC}$ and $\mathrm{CO}$ concentrations.
Acknowledgements. The authors would like to thank the crews of the NCAR C-130 and NOAA R/V Ka'imimoana for their assistance in collecting this data. This work is funded under ONR grant \#N000014-07-0031 and NSF grant \#ATM07-45368. We would also like to acknowledge P. DeCarlo, J. Jimenez, G. Kok, and E. Dunlea for the use of the IMPEX data, as well as P. Quinn and T. Bates for the VOCALS Ron Brown data (available at http://saga.pmel.noaa.gov/data). Additionally we would like to thank Rainer Volkamer and his group for the invitation to join the TAO 2009 cruise. This is SOEST contribution number 8536 .

Edited by: G. Feingold

\section{References}

Aiken, A. C., DeCarlo, P. F., Kroll, J. H., Worsnop, D. R., Huffman, J. A., Docherty, K. S., Ulbrich, I. M., Mohr, C., Kimmel, J. R., Sueper, D., Sun, Y., Zhang, Q., Trimborn, A., Northway, M., Ziemann, P. J., Canagaratna, M. R., Onasch, T. B., Alfarra, M. R., Prevot, A. S. H., Dommen, J., Duplissy, J., Metzger, A., Baltensperger, U., and Jimenez, J. L.: O/C and OM/OC ratios of primary, secondary, and ambient organic aerosols with HighResolution Time-of-Flight Aerosol Mass Spectrometry, Environ. Sci. Technol., 42, 4478-4485, 2008.

Allan, J. D., Bower, K. N., Coe, H., Boudries, H., Jayne, J. T., Canagaratna, M. R., Millet, D. B., Goldstein, A. H., Quinn, P. K., Weber, R. J., and Worsnop, D. R.: Submicron aerosol composition at Trinidad Head, California, during ITCT 2K2: Its relationship with gas phase volatile organic carbon and assessment of instrument performance, J. Geophys. Res., 109, D23S24, doi:10.1029/2003JD004208, 2004.

Allan, J. D., Baumgardner, D., Raga, G. B., Mayol-Bracero, O. L., Morales-García, F., García-García, F., Montero-Martínez, G., Borrmann, S., Schneider, J., Mertes, S., Walter, S., Gysel, M., Dusek, U., Frank, G. P., and Krämer, M.: Clouds and aerosols in Puerto Rico - a new evaluation, Atmos. Chem. Phys., 8, 12931309, doi:10.5194/acp-8-1293-2008, 2008.

Allan, J. D., Topping, D. O., Good, N., Irwin, M., Flynn, M., Williams, P. I., Coe, H., Baker, A. R., Martino, M., Niedermeier, N., Wiedensohler, A., Lehmann, S., Müller, K., Herrmann, H., and McFiggans, G.: Composition and properties of atmospheric particles in the eastern Atlantic and impacts on gas phase uptake rates, Atmos. Chem. Phys., 9, 9299-9314, doi:10.5194/acp-99299-2009, 2009.

Allen, G., Coe, H., Clarke, A., Bretherton, C., Wood, R., Abel, S. J., Barrett, P., Brown, P., George, R., Freitag, S., McNaughton, C., Howell, S., Shank, L., Kapustin, V., Brekhovskikh, V., Kleinman, L., Lee, Y.-N., Springston, S., Toniazzo, T., Krejci, R., Fochesatto, J., Shaw, G., Krecl, P., Brooks, B., McMeeking, G., Bower, K. N., Williams, P. I., Crosier, J., Crawford, I., Connolly, P., Allan, J. D., Covert, D., Bandy, A. R., Russell, L. M., Trembath, J., Bart, M., McQuaid, J. B., Wang, J., and Chand, D.: South East Pacific atmospheric composition and variability sampled along $20^{\circ} \mathrm{S}$ during VOCALS-REx, Atmos. Chem. Phys., 11, 5237-5262, doi:10.5194/acp-11-5237-2011, 2011.

Andreae, M. O. and Barnard, W. R.: The marine chemistry of dimethylsulfide, Mar. Chem., 14, 267-279, 1984.

Andreae, M. O. and Raemdonek, H.: Dimethyl sulfide in the surface ocean and the marine atmosophere: a global view, Science, 221, 
744-747, 1983.

Andreae, M. O., Elbert, W., Cai, Y., Andreae, T. W., and Gras, J.: Non-sea-salt sulfate, methanesulfonate, and nitrate aerosol concentrations and size distributions at Cape Grim, Tasmania, J. Geophys. Res., 104, 21695-21706, 1999.

Baron, P. A. and Willeke, K. (Eds.): Aerosol Measurement: Principles, Techniques and Applications (second edition), 37 chapters, 1144 pages, John Wiley \& Sons, 2001.

Bates, T., Quinn, P., Coffman, D., Johnson, J., and Middlebrook, A.: Dominance of organic aerosols in the marine boundary layer over the Gulf of Maine during NEAQS 2002 and their role in aerosol light scattering, J. Geophys. Res., 110, D18202, doi:10.1029/2005JD005797, 2005.

Bell, T. G., Poulton, A. J., and Malin, G.: Strong linkages between dimethylsulphoniopro-pionate (DMSP) and phytoplankton community physiology in a large subtropical and tropical Atlantic Ocean data set, Global Biogeochem. Cy., 24, GB3009, doi:10.1029/2009GB003617, 2010.

Berg, O. H., Swietlicki, E., and Krejci, R.: Hygroscopic growth of aerosol particles in the marine boundary layer over the $\mathrm{Pa}$ cific and Southern Oceans during the First Aerosol Characterization Experiment (ACE 1), J. Geophys. Res., 103, 16535-16545, doi:10.1029/97JD02851, 1998.

Bond, T. C., Anderson, T. L., and Campbell, D.: Calibration and Intercomparison of Filter-Based Measurements of Visible Light Absorption by Aerosols, Aerosol Sci. Technol., 30, 582-600, 1999.

Bretherton, C. S., Wood, R., George, R. C., Leon, D., Allen, G., and Zheng, X.: Southeast Pacific stratocumulus clouds, precipitation and boundary layer structure sampled along $20^{\circ} \mathrm{S}$ during VOCALS-REx, Atmos. Chem. Phys., 10, 10639-10654, doi:10.5194/acp-10-10639-2010, 2010.

Canagaratna, M. R., Jayne, J. T., Jimenez, J. L., Allan, J. D., Alfarra, M. R., Zhang, Q., Onasch, T. B., Drewnick, F., Coe, H., Middlebrook, A., Delia, A., Williams, L. R., Trimborn, A. M., Northway, M. J., DeCarlo, P. F., Kolb, C. E., Davidovits, P., and Worsnop, D. R.: Chemical and microphysical characterization of ambient aerosols with the Aerodyne aerosol mass spectrometer, Mass Spectrom. Rev., 26, 185-222, doi:10.1002/mas.20115, 2007.

Capes, G., Johnson, B., McFiggans, G., Williams, P. I., Haywood, J., and Coe, H.: Aging of biomass burning aerosols over West Africa: Aircraft measurements of chemical composition, microphysical properties, and emission ratios, J. Geophys. Res., 113, D00C15, doi:10.1029/2008JD009845, 2008.

Cavalli, F., Facchini, M. C., Decesari, S., Mircea, M., Emblico, L., Fuzzi, S., Ceburnis, D., Yoon, Y. J., O’Dowd, C. D., Putaud, J.-P., and Dell'Acqua, A.: Advances in characterization of size-resolved organic matter in marine aerosol over the North Atlantic, J. Geophys. Res., 109, D24215, doi:10.1029/2004JD005137, 2004.

Ceburnis, D., Garbaras, A., Szidat, S., Rinaldi, M., Fahrni, S., Perron, N., Wacker, L., Leinert, S., Remeikis, V., Facchini, M. C., Prevot, A. S. H., Jennings, S. G., Ramonet, M., and O'Dowd, C. D.: Quantification of the carbonaceous matter origin in submicron marine aerosol by ${ }^{13} \mathrm{C}$ and ${ }^{14} \mathrm{C}$ isotope analysis, Atmos. Chem. Phys., 11, 8593-8606, doi:10.5194/acp-11-8593-2011, 2011

Chand, D., Hegg, D. A., Wood, R., Shaw, G. E., Wallace, D., and Covert, D. S.: Source attribution of climatically important aerosol properties measured at Paposo (Chile) during VOCALS, Atmos. Chem. Phys., 10, 10789-10801, doi:10.5194/acp-1010789-2010, 2010.

Charlson, R. J., Lovelock, J. E., Andreae, M. O., and Warren, S G.: Oceanic phytoplankton, atmospheric sulfur, cloud albedo and climate, Nature, 326, 655-661, 1987.

Charlson, R. J., Schwartz, S. E., Hales, J. M., Cess, R. D., Coakley, J. A., Hansen, J. E., and Hoffmann, D. J.: Climate forcing by anthropogenic aerosols, Science, 255, 423-430, 1992.

Claeys, M., Wang, W., Vermeylen, R., Kourtchev, I., Chi, X. Farhat, Y., Surratt, J. D., Gómez-González, Y., Sciare, J., and Maenhaut, W.: Chemical characterization of marine aerosol at Amsterdam Island during the austral summer of 2006-2007, J. Aerosol Sci., 41, 13-22, 2010.

Clarke, A. D.: Aerosol Absorption by Soot in Remote Environments, Aerosol Sci. Tech., 10, 161-171, 1989.

Clarke, A. D.: A thermo-optic technique for in situ analysis of sizeresolved aerosol physiochemistry, Atmos. Environ., 25A, 635644, 1991

Clarke, A. D., Varner, J. L., Eisele, F., Tanner, R., Mauldin, L., and Litchy, M.: Particle production in the remote marine atmosophere: Cloud outflow and subsidence during ACE-1, J. Geophys, Res., 103, 16397-16409, 1998.

Clarke, A. D., Collins, W. G., Rasch, P. J., Kapustin, V. N., Moore, K., Howell, S., and Fuelberg, H. E.: Dust and pollution transport on global scales: Aerosol measurements and model predictions, J. Geophys. Res., 106, 32555-32569, 2001.

Clarke, A. and Kapustin, V.: A Pacific aerosol survey. Part I: A decade of data on particle production, transport, evolution, and mixing in the troposphere*, J. Atmos. Sci., 59, 363-382, 2002.

Clarke, A. D. and Kapustin, V. N.: Hemispheric aerosol vertical profiles: Anthropogenic impacts on optical depth and cloud nuclei, Science, 329, 1488-1492, 2010.

Cline, J. D. and Bates, T. S.: Dimethyl sulfide in the Equatorial Pacific: A natural source of sulfur to the atmosphere, Geophys. Res. Lett., 10, 949-952, 1983.

Cross, E. S., Slowik, J. G., Davidovits, P., Allan, J. D., Worsnop, D. R., Jayne, J. T., Lewis, D. K., Canagaratna, M., and Onasch, T. B.: Laboratory and ambient particle density determinations using light scattering in conjunction with aerosol mass spectrometry, Aerosol Sci. Technol., 41, 343-359, 2007.

DeCarlo, P. F., Kimmel, J. R., Trimborn, A., Northway, M. J., Jayne, J. T., Aiken, A. C., Gonin, M., Fuhrer, K., Horvath, T. Docherty, K. S., Worsnop, D. R., and Jimenez, J. L.: Fielddeployable, High-Resolution, Time-of-flight Aerosol Mass Spectrometer, Anal. Chem., 78, 8281-8289, 2006.

Drewnick, F., Hings, S. S., DeCarlo, P., Jayne, J. T., Gonin, M., Fuhrer, K., Weimer, S., Jimenez, J. L., Demerjian, K. L., Borrmann, S., and Worsnop, D. R.: A New Time-of-Flight Aerosol Mass Spectrometer (TOF-AMS) - Instrument Description and First Field Deployment, Aerosol Sci. Tech., 39, 637-658, 2005.

Drewnick, F., Schwab, J. J., Hogrefe, O., Peters, S., Husain, L., Diamond, D., Weber, R., and Demerjian, K. L.: Intercomparison and evaluation of four semi-continuous PM-2.5 sulfate instruments. Atmos. Environ., 37, 3335-3350, 2003.

Dunlea, E. J., DeCarlo, P. F., Aiken, A. C., Kimmel, J. R., Peltier, R. E., Weber, R. J., Tomlinson, J., Collins, D. R., Shinozuka, Y., McNaughton, C. S., Howell, S. G., Clarke, A. D., Emmons, 
L. K., Apel, E. C., Pfister, G. G., van Donkelaar, A., Martin, R. V., Millet, D. B., Heald, C. L., and Jimenez, J. L.: Evolution of Asian aerosols during transpacific transport in INTEX-B, Atmos. Chem. Phys., 9, 7257-7287, doi:10.5194/acp-9-7257-2009, 2009.

Gabric, A., Matrai, P., Kiene, R., Cropp, R., Dacey, J., DiTullio, G., Najjar, R., Simó, R., Toole, D., delValle, D., and Slezak, D.: Factors determining the vertical profile of dimethylsulfide in the Sargasso Sea during summer, Deep Sea Res. Part II, 55, 15051518, 2008.

Gerbig, C., Schmitgen, S., Kley, D., Volz-Thomas, A., Dewey, K., and Haaks, D.: An improved fast-response vacuum-UV resonance fluorescence CO instrument, J. Geophys. Res., 104, 16991704, 1999.

Grenfell, J. L.: An analysis of rapid increases in condensation nuclei concentrations at a remote coastal site in Western Ireland, J. Geophys. Res., 104, 13771-13780, 1999.

Gysel, M., Laborde, M., Olfert, J. S., Subramanian, R., and Gröhn, A. J.: Effective density of Aquadag and fullerene soot black carbon reference materials used for SP2 calibration, Atmos. Meas. Tech. Discuss., 4, 4937-4955, doi:10.5194/amtd-4-4937-2011, 2011.

Hawkins, L. N., Russell, L. M., Covert, D. S., Quinn, P. K., and Bates, T. S.: Carboxylic acids, sulfates, and organosulfates in processed continental organic aerosol over the southeast $\mathrm{Pa}$ cific Ocean during VOCALS-Rex 2008, J. Geophys. Res., 115, D13201, doi:10.1029/2009JD013276, 2010.

Haywood, J. M., Osborne, S. R., Francis, P. N., Keil, A., Formenti, P., Andreae, M. O., and Kaye, P. H.: The mean physical and optical properties of regional haze dominated by biomass burning aerosol measured from the C-130 aircraft during SAFARI 2000, J. Geophys. Res., 108, 8473, doi:10.1029/2002JD002226, 2003.

Heald, C. L., Kroll, J. H., Jimenez, J. L., Docherty, K. S., DeCarlo, P. F., Aiken, A. C., Chen, Q., Martin, S. T., Farmer, D. K., and Artaxo, P. A.: A simplified description of the evolution of organic aerosol composition in the atmosphere, Geophys. Res. Lett., 37, L08803, doi:10.1029/2010GL042737, 2010.

Hoffman, E. J. and Duce, R. A.: The organic carbon content of marine aerosol collected on Bermuda, J. Geophys. Res., 79, 44744477, 1976.

Howell, S. G., Clarke, A. D., Shinozuka, Y., Kapustin, V., McNaughton, C. S., Huebert, B. J., Doherty, S. J., and Anderson, T. L.: Influence of relative humidity upon pollution and dust during ACE-Asia: Size distributions and implications for optical properties, J. Geophys. Res., 111, D06205, doi:10.1029/2004JD005759, 2006.

Hsu, N. C., Herman, J. R., Bhartia, P. K., Seftor, C. J., Torres, O., Thompson, A. M., Gleason, J. F., Eck, T. F., and Holben, B. N.: Detection of biomass burning smoke from TOMS measurements, Geophys. Res. Lett., 23, 745-748, 1996.

Huffman, J. A., Jayne, J. T., Drewnick, F., Aiken, A. C., Onash, T., Worsnop, D. R., and Jimenez, J. L.: Design, modeling, optimization, and experimental tests of a particle beam width probe for the Aerodyne aerosol mass spectrometer, Aerosol Sci. Technol, 39, 1143-1163, doi:10.1080/02786820500423782, 2005.

Jaffe, D., Anderson, T., Covert, D., Kotchenruther, R., Trost, B., Danielson, J., Simpson, W., Berntsen, T., Karlsdottir, S., Blake, D., Harris, J., Carmichael, G., and Uno, I.: Transport of Asian air pollution to North America, Geophys. Res. Lett., 26, 711-
714, 1999.

Jaffe, D., Mahura, A., Kelley, J., Atkins, J., Novelli, P. C., and Merrill, J.: Impact of Asian emissions on the remote North Pacific atmosphere: Interpretation of CO data from Shemya, Guam, Midway, and Mauna Loa, J. Geophys. Res., 102, 28627-28635, 1997.

Jimenez, J. L.: Field Data Analysis Guide, online available: http://cires.colorado.edu/jimenez-group/wiki/index.php/ Field_Data_Analysis_Guide, 2010.

Keene, W. C., Maring, H., Maben, J. R., Kieber, D. J., Pszenny, A. A. P., Dahl, E. E., Izaguirre, M. A., Davis, A. J., Long, M. S., Zhou, X., Smoydzin, L., and Sander, R.: Chemical and physical characteristics of nascent aerosols produced by bursting bubbles at a model air-sea interface, J. Geophys. Res., 112, D21202, doi:10.1029/2007JD008464, 2007.

Kim, J. H. and Newchurch, M. J.: Climatology and trends of tropospheric ozone over the eastern Pacific Ocean: The influences of biomass burning and tropospheric dynamics, Geophys. Res. Lett., 23, 3723-3726, 1996.

Kleefeld, S., Hoffer, A., Krivacsy, Z., and Jennings, S. G.: Importance of organic and black carbon in atmospheric aerosols at Mace Head, on the West Coast of Ireland, Atmos. Environ., 36, 4479-4490, 2002.

Lack, D. A., Cappa, C. D., Baynard, T., Massoli, P., Covert, D. S., Sierau, B., Bates, T. S., Quinn, P. K., Lovejoy, E. R., and Ravishankara, A. R.: Bias in Filter-Based Aerosol Absorption Measurements Due to Organic Aerosol Loading: Evidence from Ambient Measurements, Aerosol Sci. Technol., 42, 1033-1041, 2008.

Langmann, B., Varghese, S., Marmer, E., Vignati, E., Wilson, J., Stier, P., and O'Dowd, C.: Aerosol distribution over Europe: a model evaluation study with detailed aerosol microphysics, Atmos. Chem. Phys., 8, 1591-1607, doi:10.5194/acp-8-1591-2008, 2008.

Lapina, K., Heald, C. L., Spracklen, D. V., Arnold, S. R., Allan, J. D., Coe, H., McFiggans, G., Zorn, S. R., Drewnick, F., Bates, T. S., Hawkins, L. N., Russell, L. M., Smirnov, A., O’Dowd, C. D., and Hind, A. J.: Investigating organic aerosol loading in the remote marine environment, Atmos. Chem. Phys., 11, 88478860, doi:10.5194/acp-11-8847-2011, 2011.

Lee, T., Sullivan, A. P., Mack, L., Jimenez, J. L., Kreidenweis, S. M., Onasch, T. B., Worsnop, D. R., Malm, W., Wold, C. E., Hao, W. M., and Collet Jr., J. L.: Chemical smoke marker emissions during flaming and smoldering phases of laboratory open burning of wildland fuels, Aerosol Sci. Technol., 44, i-v, 2010.

Lohmann, U. and Leck, C.: Importance of submicron surface-active organic aerosols for pristine Arctic clouds, Tellus, 57B, 261-268, 2005.

Maßling, A., Wiedensohler, A., Busch, B., Neusüß, C., Quinn, P., Bates, T., and Covert, D.: Hygroscopic properties of different aerosol types over the Atlantic and Indian Oceans, Atmos. Chem. Phys., 3, 1377-1397, doi:10.5194/acp-3-1377-2003, 2003.

Matthew, B. M., Middlebrook, A. M., and Onasch, T. B.: Collection efficiencies in an Aerodyne Aerosol Mass Spectrometer as a function of particle phase for laboratory generated aerosols, Aerosol Sci. Technol., 42, 884-898, 2008.

Middlebrook, A. M., Bahreini, R., Jimenez, J. L., and Canagaratna, M. R.: Evaluation of Composition-Dependent Collection Efficiencies for the Aerodyne Aerosol Mass Spec- 
trometer using Field Data, Aerosol Sci. Tech., 46, 258-271, doi:10.1080/02786826.2011.620041, 2011.

McNaughton, C. S., Clarke, A. D., Howell, S. G., Pinkerton, M., Anderson, B., Thornhill, L., Hudgins, C., Winstead, E., Diff, J. E., Scheuer, E., and Maring, H.: Results from the DC-8 inlet characterization experiment (DICE): Airborne versus surface sampling of mineral dust and sea salt aerosols, Aerosol Sci. Tech., 41, 136-159, 2007.

McNaughton, C. S., Clarke, A. D., Freitag, S., Kapustin, V. N., Kondo, Y., Moteki, N., Sahu, L., Takegawa, N., Schwarz, J. P., Spackman, J. R., Watts, L., Diskin, G., Podolske, J., Holloway, J. S., Wisthaler, A., Mikoviny, T., de Gouw, J., Warneke, C., Jimenez, J., Cubison, M., Howell, S. G., Middlebrook, A., Bahreini, R., Anderson, B. E., Winstead, E., Thornhill, K. L., Lack, D., Cozic, J., and Brock, C. A.: Absorbing aerosol in the troposphere of the Western Arctic during the 2008 ARCTAS/ARCPAC airborne field campaigns, Atmos. Chem. Phys., 11, 7561-7582, doi:10.5194/acp-11-7561-2011, 2011.

Middlebrook, A. M., Murphy, D. M., and Thomson, D.: Observation of organic material in individual marine particles at Cape Grim during the First Aerosol Characterization Experiment (ACE-1), J. Geophys. Res., 103, 16475-16483, 1998.

Miyazaki, Y., Kawamura, K., and Sawano, M.: Size distributions of organic nitrogen and carbon in remote marine aerosols: Evidence of marine biological origin based on their isotopic ratios, Geophys.Res. Lett., 37, L06803, doi:10.1029/2010GL042483, 2010.

Moore II, K. G., Clarke, A. D., Kapustin, V. N., McNaughton, C., Anderson, B. E., Winstead, E. L., Weber, R., Ma, Y., Lee, Y. N., Talbot, R., Dibb, J., Andersen, T., Doherty, S., Covert, D., and Rogers, D.: A comparison of similar aerosol measurements made on the NASA P3-B, DC-8, and NSF C-130 aircraft during TRACE-P and ACE-Asia, J. Geophys. Res., 109, D15S15, doi:10.1029/2003JD003543, 2004.

Moteki, N. and Kondo, Y.: Dependence of Laser-Induced Incandescence on Physical Properties of Black Carbon Aerosols: Measurements and Theoretical Interpretation, Aerosol Sci. Tech., 44, 663-675, 2010.

Narukawa, M., Kawamura, K., Li, S., and Bottenheim, J.: Stable carbon isotopic ratios and ionic composition of the high-Arctic aerosols: An increase in $213 \mathrm{C}$ values from winter to spring, $\mathrm{J}$. Geophys. Res., 113, D02312, doi:10.1029/2007JD008755, 2008.

Novakov, T., Corrigan, C. E., Penner, J. E., Chuang, C. C., Rosario, O., and Bracero, O. L. M.: Organic aerosols in the Caribbean trade winds: A natural source?, J. Geophys. Res., 102, 2130721313, 1997.

O’Dowd, C. D., Facchini, M. C., Cavalli, F., Ceburnis, D., Mircea, M., Decesari, S., Fuzzi, S., Yoon, Y. J., and Putaud, J.-P.: Biogenically driven organic contribution to marine aerosol, Nature, 431, 676-680, 2004.

O’Dowd, C. D. and de Leeuw, G., Marine aerosol production: a review of the current knowledge, Philos. T. Roy. Soc. A, 365, 1753-1774, 2007.

O’Dowd, C. D., Langmann, B., Varghese, S., Scannell, C., Ceburnis, D., and Facchini, M. C.: A combined organic-inorganic sea-spray source function, Geophys. Res. Lett., 35, L01801, doi:10.1029/2007GL030331, 2008.

Orellana, M. V., Matrai, P. A., Leck, C., Rauschenberg, C. D., Lee, A. M., and Coz, E.: Marine microgels as a source of cloud condensation nuclei in the high Arctic, P. Natl. Acad. Sci., 108,
13612-13617, 2011.

Pfister, G. G., Emmons, L. K., Edwards, D. P., Arellano, A., Sachse, G., and Campos, T.: Variability of springtime transpacific pollution transport during 2000-2006: the INTEX-B mission in the context of previous years, Atmos. Chem. Phys., 10, 1345-1359, doi:10.5194/acp-10-1345-2010, 2010.

Phinney, L., Leaitch, R. W., Lohmann, U., Boudries, H., Worsnop, D. R., Jayne, J. T., Toom-Sauntry, D., Wadleigh, M., Sharma, S., and Shantz, N.: Characterization of the aerosol over the subarctic north east Pacific Ocean, Deep-Sea Res. PT II, 53, 2410 2433, 2006.

Putaud, J.-P., Van Dingenen, R., Mangoni, M., Virkkula, A., Raes, F., Maring, H., Prospero, J. M., Swietlicki, E., Berg, O. H., Hillamo, R., and Makela, T.: Chemical mass closure and assessment of origin of the submicron aerosol in the marine boundary layer and the free troposphere at Tenerife during ACE-2, Tellus, 52B, 141-168, 2000.

Quinn, P. K. and Bates, T. S.: North American, Asian, and Indian haze: Similar regional impacts on climate?, Geophys. Res. Lett., 30, 1555, doi:10.1029/2003GL016934, 2003.

Quinn, P. and Bates, T.: Regional aerosol properties: Comparisons of boundary layer measurements from ACE 1, ACE 2, Aerosols99, INDOEX, ACE Asia, TARFOX, and NEAQS, J. Geophys. Res, 110, D14202, doi:10.1029/2004JD004755, 2005.

Quinn, P. K., Coffman, D. J., Bates, T. S., Welton, E. J., Covert, D. S., Miller, T. L., Johnson, J. E., Maria, S., Russell, L., Arimoto, R., Carrico, C. M., and Rood, M. J.: Aerosol optical properties measured on board the Ronald H. Brown during ACE-Asia as a function of aerosol chemical composition and source region, J. Geophys. Res., 109, D19S01, doi:10.1029/2003JD004010, 2004.

Reid, J. S., Koppmann, R., Eck, T. F., and Eleuterio, D. P.: A review of biomass burning emissions part II: intensive physical properties of biomass burning particles, Atmos. Chem. Phys., 5, 799825, doi:10.5194/acp-5-799-2005, 2005.

Russell, L. M., Hawkins, L. N., Frossard, A. A., Quinn, P. K., and Bates, T. S.: Carbohydrate-like composition of submicron atmospheric particles and their production from ocean bubble bursting, P. Natl. Acad. Sci., 107, 6652-6657, 2010.

Schwarz, J. P., Gao, R. S., Fahey, D. W., Thomson, D. S., Watts, L. A., Wilson, J. C., Reeves, J. M., Darbeheshti, M., Baumgardner, D. G., Kok, G. L., Chung, S. H., Schulz, M., Hendricks, J., Lauer, Al, Karcher, B., Slowik, J. G., Rosenlof, K. H., Thompson, T. L., Langford, A. O., Loewenstein, M., and Aikin, K. C.: Single-particle measurements of midlatitude black carbon and light-scattering aerosols from the boundary layer to the lower stratosphere, J. Geophys. Res., 111, D16207, doi:10.1029/2006JD007076, 2006.

Schwarz, J. P., Spackman, J. R., Gao, R. S., Perring, A. E., Cross, E., Onasch, T. B., Ahern, A., Wrobel, W., Davidovits, P., Olfert, J., Dubey, M. K., Mazzoleni, C., and Fahey, D. W.: The detection ef?ciency of the single particle soot photometer, Aerosol Sci. Tech., 44, 612-628, 2010.

Sciare, J., Favez, O., Sarda-Estève, R., Oikonomou, K., Cachier, H., and Kazan, V.: Long-term observations of carbonaceous aerosols in the Austral Ocean atmosphere: Evidence of a biogenic marine organic source, J. Geophys. Res., 114, D15302, doi:10.1029/2009JD011998, 2009.

Shaw, G.: Bio-controlled thermostasis involving the sulfur cycle, 
Clim. Change, 5, 297-303, 1983.

Siegel, D. A., Maritorena, S., Nelson, N. B., Hansell, D. A., and Lorenzi-Kayser, M.: Global distribution and dynamics of colored dissolved and detrital organic materials, J. Geophys. Res., 107, C123228, doi:10.1029/2001JC000965, 2002.

Simoneit, B. R. T., Schauer, J. J., Nolte, C. G., Oros, D. R., Elias, V. O., Fraser, M. P., Rogge, W. F., and Cass, G. R.: Levoglucosan, a tracer for cellulose in biomass burning and atmospheric particles, Atmos. Environ., 33, 173-182, 1998.

Spracklen, D. V., Arnold, S. R., Sciare, J., Carslaw, K. S., and Pio, C.: Globally significant oceanic source of organic carbon aerosol, Geophys. Res. Lett., 35, L12811, doi:10.1029/2008GL033359, 2008.

Shinozuka, Y., Clarke, A. D., Howell, S. G., Kapustin, V. N., and Huebert, B. J.: Sea-salt vertical profiles over the Southern and tropical Pacific oceans: Microphysics, optical properties, spatial variability, and variations with wind speed, J. Geophys. Res., 109, D24201, doi:10.1029/2004JD004975, 2004.

Singh, H., Anderson, B., Brune, W., Cai, C., Cohen, R., Crawford, J., Cubison, M., Czech, E., Emmons, L., Fuelberg, H., Huey, G., Jacob, D., Jimenez, J., Kaduwela, A., Kondo, Y., Mao, J., Olson, J., Sachse, G., Vay, S., Weinheimer, A., Wennberg, P., and Wisthaler, A.: Pollution influences on atmospheric composition and chemistry at high northern latitudes: Boreal and California forest fire emissions, Atmos. Environ., 44, 4553-4564, 2010.

Staudt, A. C., Jacob, D. J., Logan, J. A., Bachiochi, D., Krishnamurti, T. N., and Sachse, G. W.: Continental sources, transoceanic transport, and interhemispheric exchange of carbon monoxide over the Pacific, J. Geophys. Res., 106, 32571-32590, 2001.

Stephens, M., Turner, N., and Sandberg, J.: Particle identification by laser-induced incandescence in a solid-state laser cavity, Appl. Opt., 42, 3726-3736, 2003.

Sueper, D.: ToF-AMS Software Downloads, online available at: http://cires.colorado.edu/jimenez-group/ToFAMSResources/ ToFSoftware/index.html, 2010.

Turpin, B. J., Saxena, P., and Andrews, E.: Measuring and Simulating Particulate Organics in the Atmosphere: Problems and Prospects, Atmos. Environ., 34, 2983-3013, 2000.

Turekian, V. C., Macko, S. A., and Keene, W. C.: Concentrations, isotopic compositions, and sources of size-resolved, particulate organic carbon and oxalate in near-surface marine air at Bermuda during spring, J. Geophys. Res., 108, 4157, doi:10.1029/2002JD002053, 2003.

Twomey, S.: Pollution and planetary albedo, Atmos. Environ., 8, 1251-1256, 1974.

Vignati, E., Facchini, M. C., Rinaldi, M., Scannell, C., Ceburnis, D., Sciare, J., Kanakidou, M., Myriokefalitakis, S., Dentener, F., and O'Dowd, C. D.: Global scale emission and distribution of sea-spray aerosol: Sea-salt and organic enrichment, Atmos. Environ., 44, 670-677, 2010.

Virkkula, A., Ahlquist, N. C., Covert, D. S., Arnott, W. P., Sheridan, P. J., Quinn, P. K., and Coffman, D. J.: Modification, Calibration and a Field Test of an Instrument for Measuring Light Absorption by Particles, Aerosol Sci. Technol., 39, 68-83, 2005.
Warneke, C., Bahreini, R., Brioude, J., Brock, C. A., de Gouw, J. A., Fahey, D. W., Froyd, K. D., Holloway, J. S., Middlebrook, A., Miller, L., Montzka, S., Murphy, D. M., Peischl, J., Ryerson, T. B., Schwarz, J. P., Spackman, J. R., and Veres, P.: Biomass burning in Siberia and Kazakhstan as an important source for haze over the Alaskan Arctic in April 2008, Geophys. Res. Lett., 36, L02813, doi:10.1029/2008GL036194, 2009.

Weingartner, E., Saathoff, H., Schnaiter, M., Streit, N., Bitnar, B., and Baltensperger, U.: Absorption of Light by Soot Particles: Determination of the Absorption Coefficient by Means of Aethelometers, Aerosol Sci., 34, 1445-1463, 2003.

Wood, R., Bretherton, C. S., Leon, D., Clarke, A. D., Zuidema, P., Allen, G., and Coe, H.: An aircraft case study of the spatial transition from closed to open mesoscale cellular convection over the Southeast Pacific, Atmos. Chem. Phys., 11, 2341-2370, doi:10.5194/acp-11-2341-2011, 2011a.

Wood, R., Mechoso, C. R., Bretherton, C. S., Weller, R. A., Huebert, B., Straneo, F., Albrecht, B. A., Coe, H., Allen, G., Vaughan, G., Daum, P., Fairall, C., Chand, D., Gallardo Klenner, L., Garreaud, R., Grados, C., Covert, D. S., Bates, T. S., Krejci, R., Russell, L. M., de Szoeke, S., Brewer, A., Yuter, S. E., Springston, S. R., Chaigneau, A., Toniazzo, T., Minnis, P., Palikonda, R., Abel, S. J., Brown, W. O. J., Williams, S., Fochesatto, J., Brioude, J., and Bower, K. N.: The VAMOS Ocean-Cloud-Atmosphere-Land Study Regional Experiment (VOCALS-REx): goals, platforms, and field operations, Atmos. Chem. Phys., 11, 627-654, doi:10.5194/acp-11-6272011, 2011b.

Yoon, Y. J., Ceburnis, D., Cavalli, F., Jourdan, O., Putaud, J.-P., Facchini, M. C., Decesari, S., Fuzzi, S., Sellegri, K., Jennings, S. G., and O'Dowd, C. D.: Seasonal characteristics of the physiochemical properties of North Atlantic marine atmospheric aerosols, J. Geophys. Res., 112, D04206, doi:10.1029/2005JD007044, 2007.

Zhang, X., Smith, K. A., Worsnop, D. R., Jimenez, J. L., Jayne, J. T., and Kolb, C. E.: A numerical characterization of particle beam collimation by an aerodynamic lens-nozzle system: Part I. An individual lens or nozzle, Aerosol Sci. Technol., 36, 617-631, 2002.

Zhang, X. F., Smith, K. A., Worsnop, D. R., Jimenez, J., Jayne, J. T., Kolb, C. E., Morris, J., and Davidovits, P.: A numerical characterization of particle beam collimation by an aerodynamic lens-nozzle system: Part II. Integrated aerodynamic lens-nozzle system, Aerosol Sci. Technol., 38, 619-638, 2004.

Zhou, J.: Hygroscopic properties of atmospheric aerosol particles in various environments, Ph.D. thesis, 166 pp., ISBN 91-7874-1203, LUTFD2/(TFKF-1025)/1-166/(2001), Lund University, Lund, Sweden, 2001.

Zorn, S. R., Drewnick, F., Schott, M., Hoffmann, T., and Borrmann, S.: Characterization of the South Atlantic marine boundary layer aerosol using an aerodyne aerosol mass spectrometer, Atmos. Chem. Phys., 8, 4711-4728, doi:10.5194/acp-8-47112008, 2008. 